\title{
The sustainability of beach nourishments: a review of nourishment and environmental monitoring practice
}

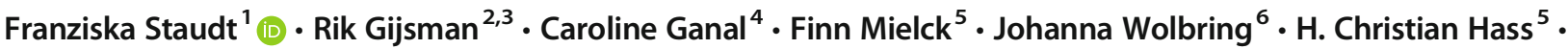 \\ Nils Goseberg ${ }^{6} \cdot$ Holger Schüttrumpf $^{4} \cdot$ Torsten Schlurmann $^{2}$. Stefan Schimmels ${ }^{1}$
}

Received: 1 August 2019 /Revised: 14 September 2020 / Accepted: 1 January 2021 / Published online: 18 March 2021

(C) The Author(s) 2021

\begin{abstract}
Beach nourishments are a widely used method to mitigate erosion along sandy shorelines. In contrast to hard coastal protection structures, nourishments are considered as soft engineering, although little is known about the cumulative, long-term environmental effects of both marine sediment extraction and nourishment activities. Recent endeavours to sustain the marine ecosystem and research results on the environmental impact of sediment extraction and nourishment activities are driving the need for a comprehensive up-to-date review of beach nourishment practice, and to evaluate the physical and ecological sustainability of these activities. While existing reviews of nourishment practice have focused on the general design (motivation, techniques and methods, international overview of sites and volumes) as well as legal and financial aspects, this study reviews and compares not only nourishment practice but also the accompanying assessment and monitoring of environmental impacts in a number of developed countries around the world. For the study, we reviewed 205 openly-accessible coastal management strategies, legal texts, guidelines, EIA documents, websites, project reports, press releases and research publications about beach nourishments in several developed countries around the world (Germany, Denmark, the Netherlands, Belgium, Spain, UK, USA and Australia). Where information was not openly available, the responsible authorities were contacted directly. The study elaborates on the differences in coastal management strategies and legislation as well as the large dissimilarities in the EIA procedure (where applicable) for both marine sediment extraction and nourishment activities. The spatial disturbance of the marine environment that is considered a significant impact, a factor which determines the need for an Environmental Impact Assessment, varies substantially between the countries covered in this study. Combined with the large uncertainties of the long-term ecological and geomorphological impacts, these results underline the need to reconsider the sustainability of nourishments as "soft" coastal protection measures.
\end{abstract}

Keywords Coastal protection $\cdot$ Coastal management $\cdot$ Beach nourishment $\cdot$ Sustainability $\cdot$ Ecology $\cdot$ Environmental impact assessment

Franziska Staudt

staudt@fzk.uni-hannover.de

1 Forschungszentrum Küste, Leibniz University Hannover and Technische Universität Braunschweig, Merkurstraße 11, 30419 Hannover, Germany

2 Leibniz University Hannover, Ludwig Franzius Institute of Hydraulic, Estuarine and Coastal Engineering, Nienburger Straße 4, 30167 Hannover, Germany

3 Marine and Fluvial Systems, Faculty of Engineering Technology, University of Twente, P.O. Box 217, 7500 AE,

Enschede, Netherlands
4 Institute of Hydraulic Engineering and Water Resources Management, RWTH Aachen University, Mies-van-der-Rohe-Straße 17, 52074 Aachen, Germany

5 Alfred Wegener Institute, Helmholtz Centre for Polar and Marine Research, Wadden Sea Research Station, Hafenstraße 43, Sylt, 25992 List, Germany

6 Technische Universität Braunschweig, Leichtweiß-Institute for Hydraulic Engineering and Water Resources, Beethovenstraße 51a, 38106 Braunschweig, Germany 


\section{Introduction}

The world's coastal zones are facing massive challenges, e.g. through coastal infrastructure developments, maritime traffic, tourism and exploitation of marine resources, but also through effects of sea-level rise, increasing population and coastal erosion (e.g. Ramesh et al. 2015). With the majority of megacities (>8 million inhabitants) being located within the coastal zone (Brown et al. 2013), the growing pressure on coastal ecosystems demands the careful balancing of human activities, developments and natural space. For the year 2060 a study by Neumann et al. (2015) projects that approximately $12 \%$ of the global population will live in 'low-elevation coastal zones' (LECZ), i.e. coastal areas with an elevation of less than $10 \mathrm{~m}$ above mean sea level which are particularly prone to flooding. By then, the authors expect a population density in the LECZ between 405 and 534 people $/ \mathrm{km}^{2}$ (it was 241 people $/ \mathrm{km}^{2}$ in the year 2000). In addition, the combination of sea-level rise, an increase in frequency and intensity of extreme events, such as heavy precipitation (IPCC 2018), and the limitation of sediment sources or lateral transfer budgets (e.g. rivers or updrift beaches which are cut off through dams or coastal structures) leads to the erosion of sandy beaches in many areas. Especially urban areas lack natural, dynamic dry land behind the beaches (e.g. dune systems or coastal forests) which might serve as buffer enhancing coastal protection levels. Additionally, the inland migration of eroding beaches and coastal ecosystems is often limited by coastal development, causing the so-called coastal squeeze (Pontee 2013). This coastal squeeze aggravates the problem of erosion and subsequently endangers the integrity of both ecosystem and infrastructure. Considering all these challenges, novel sustainable management strategies and spatial planning tools like Integrated Coastal Zone Management (ICZM) (UNEP/MAP/ PAP 2008), the ecosystem approach or an ecological engineering approach to management (Cheong et al. 2013; Temmerman et al. 2013) aim at the holistic, environmentally friendly and sustainable development of the world's coastlines.

Especially in view of rising sea levels (IPCC 2018) and recent severe coastal flood events (e.g. Woodruff et al. 2013), physically as well as ecologically sustainable coastal protection has now become focal point in planning and management for developed, i.e. heavily populated coastlines. For the past few decades, dune, beach and shoreface nourishments have been termed an environmentally friendly alternative or addition to hard coastal protection structures, such as groins, revetments or breakwaters (Hamm et al. 2002; Schoonees et al. 2019). Unlike hard structures, these "soft" or "green" measures are believed to adapt to rising sea levels or changing sea states, and do not lead to scour or erosion of downdrift beaches (Dean 2002; Bird and Lewis 2015). Beach nourishments increase the beach volume and can be used to restore or create new habitats for coastal and marine flora and fauna, such as seabirds, sea turtles etc. (National Research Council 1994; Jones and Mangun 2001; van Egmond et al. 2018). In addition, nourishments can enhance or replace hard coastal protection structures and subsequently contribute to the renaturation of engineered coastlines (Capobianco and Stive 2000). However, to sustain their flood protection functionality, inspection and re-nourishments intervals are shorter than for typical hard structures, leading to higher maintenance costs (Schoonees et al. 2019). Many coastal countries around the world are therefore carrying out beach nourishments on a regular basis as a suitable means of erosion mitigation and coastal protection (e.g. Cooke et al. 2012; Hamm et al. 2002; Hanson et al. 2002; Luo et al. 2016).

In most cases sand for nourishments is extracted from compatible offshore borrow sites and pumped or shipped to shore. In fewer cases the material is quarried from inland sites. At the shore (dumping site) the material is placed either on the beach (beach or shore nourishment), sublittoral in the nearshore zone (shoreface nourishment) or on the sea- or land side of dunes either to reinforce or to retrofit a natural dune system (dune nourishment). Borrow sites are chosen according to sediment availability and compatibility (deposit size, grain size and colour), but also depend on economic considerations (distance from the nourishment site). Sand is also recycled from downdrift coastal stretches, where it has accumulated due to the littoral drift, e.g. in front of coastal structures. In some cases, so-called bypasses are used to redirect these sediment deposits to the other (downdrift) site of the coastal structure, where a lack of incoming sediment would otherwise result in a receding coastline, which often imperils coastal settlements. Some beaches are regularly re-profiled by bulldozers, e.g. after heavy storms that have shifted sediment in the cross-shore direction (i.e. transported offshore). Further information about nourishment design and application techniques can be found in Dean (2002) and Bird and Lewis (2015) as well as in the guidelines listed in the Section "Guidelines for design and monitoring of efficiency and environmental impacts". In contrast to hard coastal protection measures, nourishments are generally considered temporary solutions with limited lifetimes that require regular - sometimes annual - maintenance (i.e. re-nourishment).

Existing reviews of beach nourishment practice like Hanson et al. (2002) and Bird and Lewis (2015) have primarily focused on the general nourishment design (motivation, techniques and methods, international overview of nourishment sites and volumes) and legal as well as financial aspects. New legal settings (e.g. the Marine Strategy Framework Directive in the EU, cf. European Commission, 2008) and recent research on the environmental impact of beach nourishment activities, however, motivate a comprehensive up-todate review of beach nourishment strategies (and adjustment of the nourishment practice, where required) with a focus on 
environmental impacts. The study at hand hence reviews and compares not only beach nourishment practice but also the accompanying assessment and monitoring of environmental impacts in different developed countries around the world, the latter not having been addressed in previous reviews.

Below we first provide a brief introduction to a selection of observed environmental impacts of extraction and nourishment activities (Environmental impacts of sediment extraction and nourishment activities) and the procedure of the (compulsory) Environmental Impact Assessment (EIA) as directed by environmental law (The environmental impact assessment), followed by a description of the review methods (Methods). The main part of the paper provides a comprehensive overview of beach nourishment strategies (Framework and strategies), existing nourishment design guidelines (Guidelines for design and monitoring of efficiency and environmental impacts) and the environmental monitoring associated with nourishment activities (Practical assessment of environmental impacts) in a number of developed countries. Based on the main part, we discuss the international differences in nourishment strategies (Strategic framework and current practice) and accompanying environmental monitoring (Differences in environmental monitoring practice and legislation) as well as the limitations of the current environmental monitoring practice (Limits of EIA as tool). The paper closes with an evaluation of the sustainability of beach nourishments as coastal protection measures (Evaluating the sustainability of beach nourishments). Improving the environmental sustainability of coastal protection, while also accounting for the long-term morphological sustainability in view of rising sea levels, is a crucial step towards the implementation of an ecosystem approach to coastal management.

\section{Environmental impacts of sediment extraction and nourishment activities}

Although often considered an ecologically sustainable coastal protection measure, the extraction, transport and deposition of sediment can have severe short-term and potential long-term impacts on the environment. This section gives a brief summary of several known negative impacts on the coastal marine environment. To mitigate negative impacts, design guidelines for nourishments (Guidelines for design and monitoring of efficiency and environmental impacts) usually include a number of recommendations based on previous experience, such as scheduling the activities outside of nesting or recruitment periods of marine species, matching borrow material with the native sediment, creating a profile similar to the natural beach slope, decreasing re-nourishment frequency, or nourishing in intermittent sections to allow quick resettlement of the disturbed areas. However, even in compliance with these mitigation measures, beach nourishment projects can have a variety of environmental impacts.
At the extraction site, habitats are destroyed as benthic organisms are extracted with the borrow material (e.g. Rosov et al. 2016; van Dalfsen and Essink 2001; Wooldridge et al. 2016). Depending on the dredging technique, dredging pits of up to $20 \mathrm{~m}$ depth can form and act as sinks for fine sediment, leading to a substantial change of the original sediment composition, as observed in dredging pits in the North Sea (de Jong et al. 2015; Mielck et al. 2018; Zeiler et al. 2004). Benthic communities have been found to recover as soon as the native sediment properties are restored, a process which strongly depends on local hydrodynamics and hydrographic properties of the borrow site (Zeiler et al. 2004; CSA International, Inc. et al. 2010). In case the sediment properties change permanently, biodiversity may drop and opportunistic species (and predators) may start to dominate (e.g. review by Greene 2002; de Jong et al. 2015), i.e. the habitat composition changes. Several studies have estimated that deep extraction pits, especially those located in deeper water with low flow velocities, will not refill (and thus not recover) for decades (e.g. de Jong et al. 2015; Mielck et al. 2018; Zeiler et al. 2004). However, ecosystem-based landscaping inside extraction areas in the North Sea, e.g. in form of sand bars, has been found to facilitate the recovery of macrozoobenthos and demersal fish (De Jong et al. 2014; de Jong et al. 2015). In addition to the direct disturbance caused by excavation, sediment plumes and increased turbidity from dredging activities can cover and suffocate sessile, filterfeeding organisms and lead to reduced light levels and photosynthesis (e.g. Erftemeijer et al. 2012; Bell et al. 2015; Jones et al. 2016). Suction dredging can cause a long-lasting increase in suspended particulate matter (SPM) in the water column and subsequent reduced light levels, which in turn can have dramatic impacts on phytoplankton production and thus on the whole coastal ecosystem (e.g. De Jonge 1983; Essink 1999; De Jonge and Schückel 2019). Furthermore, the dredging and transport activities themselves can directly disturb marine mammals and turtles, e.g. through noise or collision with dredging equipment (Greene 2002).

Direct environmental impacts at the nourishment site include coverage (and subsequent suffocation) of benthic organisms (e.g. Colosio et al. 2007; Schlacher et al. 2012) and a shift in median grain size and grain-size distribution, in case the chosen borrow material is different from the native material. If the grading of the material is too wide, cliffs or escarpments can develop at the beach, as described for example by McFarland et al. (1994) and She et al. (2007) for shingle beaches in the UK. Escarpments can reduce beach amenity and endanger beach users, and can impede the accessibility for marine fauna like nesting sea turtles (Crain et al. 1995). Similar to the effects at the borrow site, a shift in benthic habitat composition has been observed (e.g. Leewis et al. 2012; review by Speybroeck et al. 2006). The disappearance or reduction of certain species can subsequently affect 
predators (e.g. birds or fish) which may have to leave the affected area (Vanden Eede et al. 2014; Wooldridge et al. 2016). The consequences of these processes are not fully understood; however, it has been shown that a shift in species can eventually also affect local fisheries and economy (Essink et al. 1997; Vanden Eede et al. 2014). A study on the abundance of the bivalve mollusc Spisula subtruncata along the Dutch coastline found no causal relation between the decline of the species and an increase in shoreface nourishments, although the nourishments may have had an additional impact on the coastal ecosystem (Baptist and Leopold 2009). Studies investigating the impacts of beach nourishments in turtle nesting areas found several impacts on nesting and hatching success that could be related to sediment grain size and colour, which ultimately affect beach characteristics such as beach slope and sand temperature, respectively (Holloman and Godfrey 2008; Brock et al. 2009). It should be noted that certain benthic infauna in the dynamic intertidal zone, e.g. polychaetes, amphipods, bean clams and mole crabs, have been found to recover within one year (e.g. Leewis et al. 2012; Menn et al. 2003; Schlacher et al. 2012; Wooldridge et al. 2016), as they are used to adapt to a changing environment. However, recovery rates vary significantly between studies and species, and in several cases the observed species had not recovered at the end of the monitoring period (e.g. Rosov et al. 2016; Wooldridge et al. 2016). In general, it has been found that organisms in less dynamic areas of the coastal profile, i.e. at larger water depths or in the upper beach profile, have longer recovery rates (Rakocinski et al. 1996; Janssen and Mulder 2005).

Although a number of studies have investigated the effects of extraction and nourishment activities on different (key) species, there still is a lack of understanding regarding many underlying biological processes and impact mechanisms, e.g. the process of disturbance and survival of organisms during nourishment activities (Speybroeck et al. 2007) or possible cumulative impacts (Greene 2002). Subsequently, it is unknown whether these activities might have a long-term impact on the environment.

\section{The environmental impact assessment}

A widely used planning tool to evaluate environmental impacts of a proposed construction project during the approval process is an Environmental Impact Assessment, EIA (e.g. Carroll and Turpin 2002). In general, EU legislation requires an EIA for activities which are likely to have significant effects on the (marine) environment. In the countries of the EU, the EIA Directive (Directive 2014/52/EU of the European Parliament and of the Coucil 2014) is transferred into national legislation. In the USA (National Environmental Policy Act (NEPA) 1970) and Australia (Environment Protection and Biodiversity Conservation Act (EPBC) 1999) similar legislation exists to ensure the examination of possible environmental impacts before a project is licensed, i.e. a permission is granted. A so-called screening is conducted to decide whether an EIA is mandatory for the planned activity, which usually applies to sediment extraction from the seafloor and sometimes applies to large nourishment activities. The criteria under which an EIA is required during the licensing process differ between countries, as will be described later in this study (cf. Practical assessment of environmental impacts).

If an EIA is required, a study has to be conducted, often following a distinct and structured procedure to assess the expected environmental impacts. The EIA report includes a comprehensive description of the proposed project, alternative measures and do-nothing scenarios. This is followed by an inventory of all elements of the environment, i.e. flora, fauna, biodiversity, soil, water, climate, air, landscape, humans and cultural heritage (Carroll and Turpin 2002). Data for each element must be collected in-situ or retrieved from existing studies. The importance of the element is then rated according to its level of exposure, nativeness, importance as habitat, importance to abiotic environmental services and importance to human health and well-being. Subsequently, the likely impacts of the proposed project on each element are described and the magnitude of the impact is estimated (ranging from negligible to very strong and depending on the intensity, duration and spatial scale of the impact). The importance of the environmental element and the magnitude of the potential impacts are then combined to assess the significance of the environmental impact. It is interesting to note that the nativeness of an environmental element, such as soil (or sediment), is reduced once it has been altered by human activities, e.g. by a previous nourishment. Consequently, the importance of the element degrades, leading to a lower significance of the expected environmental impact.

The EIA report and any required supplementary documents can also include plans to minimize impacts, enhanced protection schemes or compensation measures: Activities can for example be confined to certain periods of the year, when marine organisms are less vulnerable or abundance in the area is naturally lower. Compensation measures might include the creation of new habitats, such as coastal wetlands. The EIA report is then submitted to the responsible regulatory body and forms the basis for evaluation and decision about a license for the activity. At this stage, the report incl. a non-technical summary should be made available to the public, who then may be allowed to participate and intervene. Once a project has been approved, its maintenance, i.e. a reoccurring re-nourishment in the case of beach nourishment activities, usually does not require a new EIA. It 
has to be noted that the environmental impact assessment is only one of several steps in the planning approval or licensing procedure of a construction project (Carroll and Turpin 2002).

This study focuses on the (recommended) environmental monitoring that should be conducted within the process of fulfilling the national environmental policies. As the terminology of country-specific documents that are required for the licensing process differs (environmental statement/ES, environmental assessment/EA etc.), we will hereafter use the term "EIA report" when referring to the written proof of the EIA procedure. If other documents are required instead or in addition to the EIA, further details about the procedure might be given.

\section{Methods}

To evaluate the current shore nourishment practice in Germany, Denmark, the Netherlands, Belgium, Spain, the UK, the USA and Australia, a comprehensive deskstudy review of available coastal management strategies, legal texts, guidelines, EIA documents (EIA reports, scoping reports, etc.), websites (coastal/environmental authorities, executing companies or individual projects, databases), project reports (research or industry), press releases and research publications (e.g. case studies) was conducted for each country. In some cases, coastal management experts and responsible authorities were contacted directly to complete the available information. It has to be noted that many of the over 200 used references constitute non-peer-reviewed resources (some of which might not be available permanently, i.e. websites or online databases). Table 1 shows a list of the document types that were used to gather the up-to-date information in chapter 3 of this study. The full document list is provided as Online Resource (Document_List.xlsx).

\section{International nourishment practice}

\section{Framework and strategies}

Strategies for coastal protection vary between the countries considered in this review. A description of several strategic aspects, e.g. responsibilities, management strategies, nourishment volumes and reoccurrence of nourishment (repetition rates) is presented below. Further information on the technical nourishment design is given in Table 2.

\section{Germany}

In Germany the federal states (Lower Saxony, SchleswigHolstein, Mecklenburg-Vorpommern, Hamburg and Bremen) bordering the North and Baltic Seas are responsible for coastal protection and have developed legally binding long-term strategies individually. However, only SchleswigHolstein, Lower Saxony and Mecklenburg-Vorpommern conduct nourishments along their open sandy coastlines (StALU MM 2009; NLWKN 2010; MELUR-SH 2012). The overarching objective of these binding strategies is the protection of people and infrastructure against impacts from the sea. Average annual nourishment volumes are 1.9 million $\mathrm{m}^{3}$ in Germany, of which about 1.2 million $\mathrm{m}^{3}$ are nourished on the North Sea island of Sylt. The island has been nourished with a cumulative total of 41.5 million $\mathrm{m}^{3}$ of sand between 1972 and 2011. When nourishment activities started in the 1970s up to the end of the 1980s, campaigns comprised large nourishment volumes which were designed to have a lifetime $>5$ years. From the 1990s onwards the focus has shifted towards smaller nourishment volumes with higher re-nourishment frequencies (MELUR-SH 2012). While nourishment locations are alternated at some sites on Sylt, beaches at the municipalities of List, Kampen, Westerland and Hörnum depicting important touristic landmarks are re-nourished every year. The coastal protection strategy of Schleswig-Holstein (MELUR-SH
Table 1 Types of documents reviewed in the study

\begin{tabular}{ll}
\hline Document type & Number of documents \\
\hline Coastal management strategies (authorities) & 21 \\
Legal texts & 8 \\
Guidelines \& recommendations & 15 \\
EIA reports and accompanying studies & 23 \\
Nourishment databases & 2 \\
Reports (by authorities \& companies) & 18 \\
Reports (research projects) & 19 \\
Press releases \& newspaper articles & 7 \\
Research publications (journal papers, books, conference proceedings, theses) & 87 \\
Other & 5 \\
Total & 205 \\
\hline
\end{tabular}




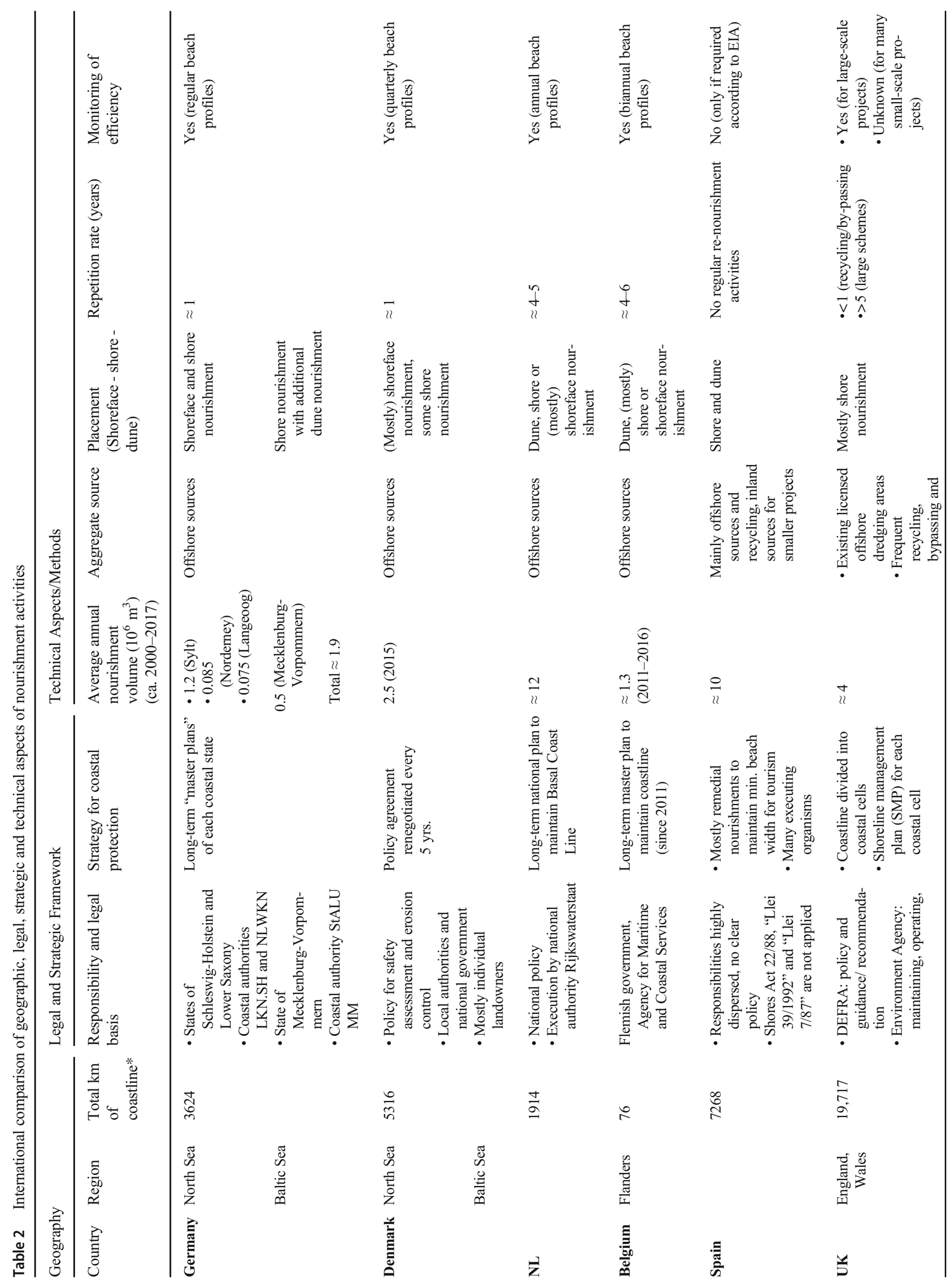




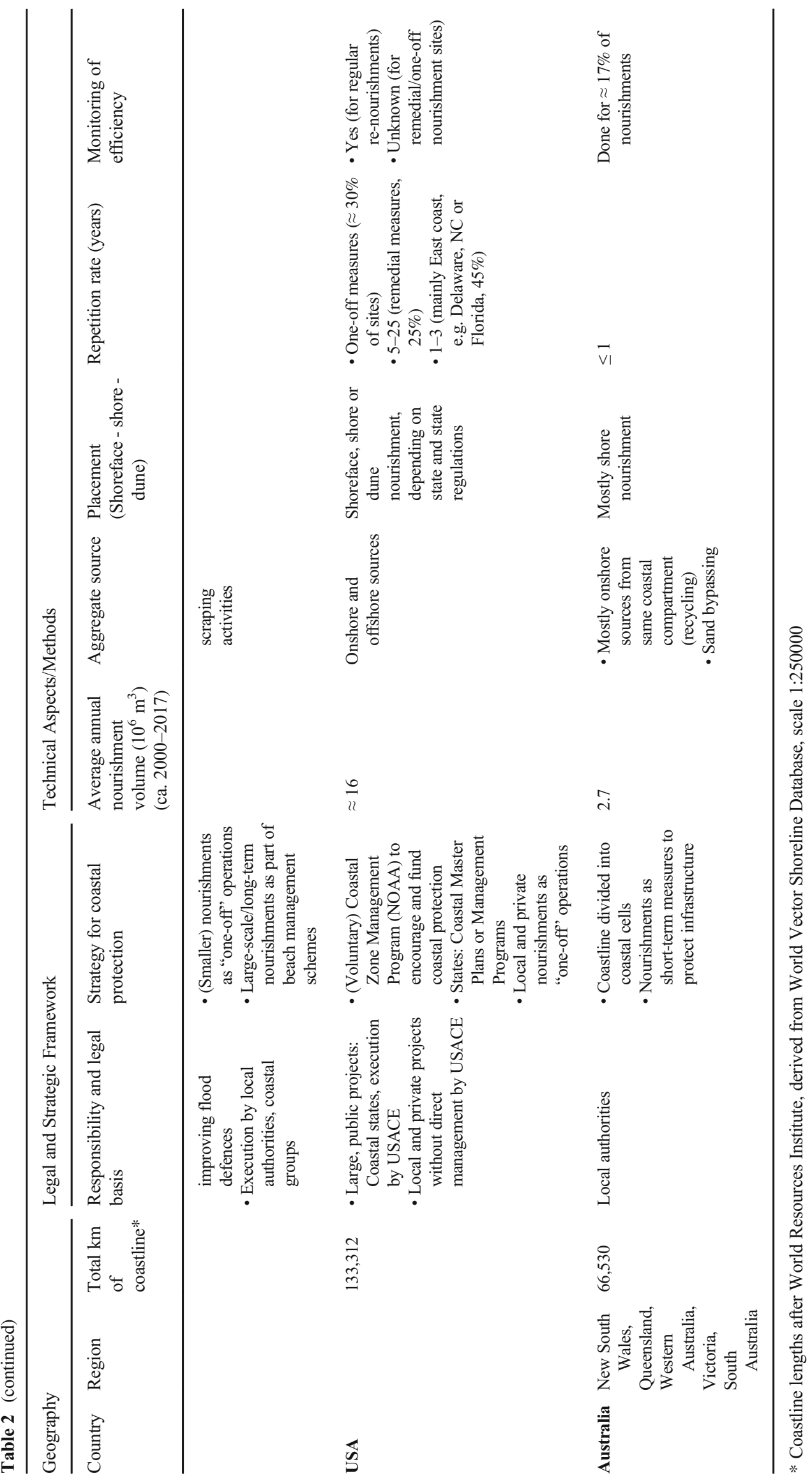


2012) estimates a required annual nourishment volume of 1 million $\mathrm{m}^{3}$ to maintain the coastline of the island, which is equivalent to an annual investment into dredging activities of 5-6 million $€$. Beach profiles are taken annually to evaluate nourishment efficiency and base future nourishment planning on.

\section{Denmark}

The Danish Coastal Authority (Kystdirektoratet) has set up a separate policy for safety assessment and erosion control, which is used to manage the nourishment activities in critically eroding areas. This policy is re-negotiated every five years. From 1983 until 2015, Denmark has nourished its coastlines along the North and Baltic Seas with an average of 1.8 million $\mathrm{m}^{3}$ per year; in 2015 the annual nourishment volume had reached 2.5 million $\mathrm{m}^{3}$. Nourishment activities focus on a stretch between Lodbjerg and Nymindegab at the West coast of Denmark (Kystdirektoratet 2015a, b). The efficiency of the nourishment strategy is evaluated through annual beach profiles. In case the nourishments contribute to national flood safety (i.e. in highly erosive areas at the West coast), the activities are planned, financed and maintained by the government and local authorities; in all other cases the individual landowners are responsible for coastal protection (Kystdirektoratet 2015a). The average annual nourishment costs in Denmark approximate 10 million $€$.

\section{The Netherlands}

The Netherlands have a national strategy to maintain the shoreline of 1990, which is implemented by the national Ministry of Infrastructure and Water Management (Hillen and Roelse 1995). Activities in the Netherlands have an average repetition rate, i.e. lifetime of the nourishment body, of four to five years with an average annual nourishment volume of 12 million $\mathrm{m}^{3}$ (Rijkswaterstaat 2017). Beach profiles are recorded every year to assess nourishment efficiency and demand. In recent years, the Dutch authorities and research institutes have been testing the behaviour of large-scale, so-called mega nourishments (the 2011 Zandmotor and the 2016 Hondsbossche en Pettemer Zeewering (HPZ)) with initial volumes of 21.5 and 35 million $\mathrm{m}^{3}$ and design lifetimes of approximately 20 and 50 years, respectively (e.g. de Schipper et al. 2016; Karman et al. 2013; Stive et al. 2013). The design of these mega nourishment follows the recommendations to nourish very large amounts with long repetition rates, in order to avoid frequent disturbances of the ecosystem. The Zandmotor nourishment is accompanied by a number of interdisciplinary research studies investigating the long-term changes and impacts on hydrodynamics, sediment properties, groundwater and the ecosystem, but also on recreation and management (cf. Oost et al. 2016 for a first overview of results).

\section{Belgium}

In Belgium the region of Flanders has developed a long-term master plan (Masterplan for Coastal Safety) for the protection of the Belgian coastline (MDK 2011). Recent nourishment volumes in Belgium are relatively high since the approval of the new masterplan in 2011. Between 2011 and 2016, 1.3 million $\mathrm{m}^{3}$ have been nourished per year with a focus on the identified weak spots in the coastal defence system (so-called 'weak links') along the Belgian shoreline. Generally, renourishment is carried out after 4-6 years; however, more frequent maintenance works are conducted in case of storm impacts (Afdeling Kust 2018). The beaches are profiled twice per year to evaluate the efficiency of the protection measures.

\section{Spain}

Despite a large annual nourishment volume of about 10 million $\mathrm{m}^{3}$, the responsibility for beach nourishment activities in Spain is highly dispersed over several governmental bodies and authorities (Ariza 2011). It is noteworthy that beach nourishments are only accepted along artificial urban beaches or at beach resorts which are critical for tourism (Gracia et al. 2013). Most activities are remedial nourishment measures to restore the "beach functionality", i.e. a minimum beach width (usually $30-60 \mathrm{~m}$ ). As tourism is an important economical factor in Spain, nourishment activities focus on tourist areas (e.g. the Mediterranean or the coast of Andalusia) and beach amenity is regarded as main function of a beach. Many largescale activities $\left(>100,000 \mathrm{~m}^{3}\right)$ are conducted along the Mediterranean Sea and Andalusia (Gracia et al. 2013). Monitoring of nourishment efficiency by beach profiling is only conducted if specifically requested in the EIA (cf. Practical assessment of environmental impacts). Despite the existence of a comprehensive database about the physical characteristics of Spanish beaches, and although several approaches have been made to implement the ICZM approach in Spain and to develop a national strategy for coastal management, no national master plan exists (Barragán Muñoz 2010; Sanò et al. 2010). It has been hypothesized by Ariza (2011) that the absence of a responsible institution for coastal management might be the main reason. However, a 2016 strategy for climate change adaptation of the Spanish coast lists beach nourishments and artificial dunes as measures to counter coastal erosion (MAPAMA 2016).

\section{UK: England and Wales}

Approximately $28 \%$ of the coastline of England and Wales are receding, $6 \%$ experience erosion of more than $1 \mathrm{~m}$ per year (Burgess et al. 2007). Especially the sand/gravel beaches in the South and East of England have to be nourished to mitigate steady erosion, while the rocky shorelines of the 
Southwest experience only little or no change (Burgess et al. 2007; Moses and Williams 2008). The shoreline is divided into coastal cells, which are based on the concept of physically interconnected sediment cells, as developed in the EU research projects EUROSION and CONSCIENCE (van Rijn 2010; Van Rijn 2011). The coastal cells are managed by socalled coastal groups, consisting of members of the local coastal authorities, which develop Shoreline Management Plans (SMPs) for the cell(s) within their responsibility. Besides many small one-off operations (like bypassing, recycling or re-profiling of beaches) to mitigate erosion or to repair storm damage, several large-scale projects have been re-nourished in regular intervals over the past decades (e.g. the Lincshore project or the Bournemouth Beach Management Scheme) to strengthen the coastal resilience (Bournemouth Borough Council 2017; DEME 2017; Environment Agency 2017). While the efficiency of large-scale schemes is monitored through regular beach profile collections, it is unknown for many one-off nourishment sites. Coastal managers in the UK have also investigated the potential effectiveness of a mega-nourishment along the UK coastline (Brown et al. 2016) and are designing a large-scale 'sandscaping' project in Norfolk with construction expected to start in 2019. Due to the predominantly rocky shoreline, only few beaches in Scotland have been subject to nourishment in the past (Werritty 2007).

\section{USA}

Similar to the European shoreline, beach nourishments are the preferred coastal management tool in the USA to adapt to sealevel rise, to reduce potential storm damage and to "repair" storm-damaged beaches (Young and Coburn 2017; Young 2019). Additionally, it is estimated that about one billion $\mathrm{m}^{3}$ of sediments were removed from the beaches since 1930 by the work of man for e.g. river damming or other constructions, which sometimes increases the vulnerability of the coasts (Campbell and Benedet 2006). A paradigm change in coastal management has been triggered by heavy hurricanes like the “Atlantic Ash Wednesday Nor'easter" in 1962 (Jarrett 1987) and was reinforced more recently following the major impacts of Hurricane Sandy along the shores of New York, New Jersey and Maryland in 2012. The individual coastal states are responsible for strategies and policies regarding beach nourishments, which is why no nation-wide, long-term strategy exists. The legislative framework for the state policies, the Coastal Zone Management Act (1972), which includes the (voluntary) national Coastal Zone Management (CZM) Program, enables the single states to pass individual laws enforcing beach nourishments (National Research Council 1995). In particular those states which carry out a large number of beach nourishments (e.g. North Carolina, California and Florida) have incorporated this concept into their legislation (Hedrick 2000). In total, 21 states had developed dedicated beach nourishment policies by the year 2000. In addition, six states (California, Florida, North Carolina, Ohio, Rhode Island and South Carolina) have issued their own explicit guidelines on where to deposit sand during beach nourishment projects (Hedrick 2000). While implementation of the CZM Program is conducted and financed at state level, the program is administered by the National Oceanic and Atmospheric Administration (NOAA). In addition, many projects are conducted and funded locally or by private landowners, when need for coastal protection arises.

More than 200 nourished areas stretch along $600 \mathrm{~km}$ of the US coast (Campbell and Benedet 2006). The National Beach Nourishment Database (ASBPA 2017) shows that 645 million $\mathrm{m}^{3}$ of sand have been placed on the shorelines since 1972, with an average annual nourishment volume of about 16 million $\mathrm{m}^{3}$. The majority of beach nourishments in the USA take place along the East Coast as protection of the hinterland against hurricanes and storms: the states of New Jersey, North Carolina and Florida nourish the highest volumes with up to 4.3 million $\mathrm{m}^{3}$ sand per year in New Jersey (ASBPA 2017). While many beach nourishments in the USA are executed only once or with a repetition rate of 10 to 20 years, only a few sections are nourished every one to two years (mainly in Delaware, North Carolina, and Florida). The efficiency of these regular nourishments is monitored using beach profiles in order to determine erosion rates (USACE, 2002). Research on coastal morphodynamics and beach nourishments has been conducted since the 1950s. The outcomes especially regarding nourishment efficiency, environmental impacts and environmental benefits have been compiled by the National Research Council and the American Shore and Beach Preservation Association (ASBPA) to inform future nourishment projects (National Research Council 1994, 1995; Rosov et al. 2016). Detailed instructions for the planning and execution of beach nourishments have been issued by the US Army Corps of Engineers, USACE (e.g. Coastal Engineering Manual, US Army Corps of Engineers 2002). Since the 1970s, computer models have become increasingly important in the planning of nourishment activities (Davison et al. 1992).

\section{Australia}

Coastal management in Australia varies between the different states and territories. On a state level, coastal councils are coordinating the coastal management strategies, which are based on sediment cells and thus implemented on a local level (Harvey and Caton 2010). Despite the long sandy coastline of Australia, nourishment activities focus on few urban areas: Starting from the 1970s, beach nourishments have been conducted predominantly along urban areas such as Adelaide, the Gold Coast and around Port Phillip Bay (Bird and Lewis 
2015). Thus, the main goal of nourishment is the protection of coastal infrastructure, followed by recreation and public safety. A majority of the nourishment projects is of small size, consisting of a volume smaller than $5000 \mathrm{~m}^{3}$. Those projects mainly serve as mitigation to storm-surge induced erosion and shift sediment within the same coastal compartment. Only $8 \%$ of the nourishment projects utilize sand originating from offshore sources (Cooke et al. 2012). The storm-surge induced damage along the coast of Adelaide has been reduced to $5 \%$ of the pre-nourishment damage, indicating the success of beach nourishments. This effect is attributed to the restoration of coastal dunes by the additional sand supply (Tucker et al. 2005). Aiming at restoring the longshore transport, larger nourishment volumes are moved by permanent bypass systems such as the Tweed River Sand Bypassing Project. Only about $17 \%$ of nourishment activities are monitored regarding their efficiency (Cooke et al. 2012).

\section{Guidelines for design and monitoring of efficiency and environmental impacts}

Several authorities, non-profit bodies and industry associations have published guidelines dealing with coastal erosion and different types of coastal protection. These guidelines are usually based on experience ("lessons learned") and engineering recommendations for efficient coastal protection, but also incorporate environmental considerations. Comprehensive experiences with nourishment activities in the USA, covering engineering as well as environmental aspects, have been gathered by the National Research Council (1994, 1995). A widely referenced document focusing on US coasts is the Coastal Engineering Manual (CEM) by the US Army Corps of Engineers (US Army Corps of Engineers 2002), which contains a separate chapter about beach nourishments. The additional manual "Environmental Engineering for Coastal Shore Protection" contains recommendations for environmental monitoring programmes, data collection, habitat assessment etc. (US Army Corps of Engineers 1989). The CIRIA Beach Management Manual (Rogers et al. 2010) and the Shoreline Management Guidelines published by DHI (Mangor et al. 2017) are more recent publications including guidelines for beach nourishments. While the former manual gives a detailed description of beach management practice (and legal framework) in the UK, the latter is intended as a practical handbook for international stakeholders, e.g. coastal managers, planners and engineers. These publications are based on experience as well as numerical and physical modelling and include comprehensive information about the assessment of environmental impacts during nourishment activities. Corresponding chapters include e.g. descriptions of the formal EIA process and recommendations for ecological field measurements on certain spatial and temporal monitoring scales. The "Committee for Coastal Protection Measures of the German
Association of Geotechnics and the German Port Technology Association" (Ausschuss für Küstenschutzwerke der Deutschen Gesellschaft für Erd- und Grundbau e.V. und der Hafenbautechnischen Gesellschaft e.V.) has published "Recommendations for the Design of Coastal Protection Measures" for Germany, which include a chapter about beach nourishments (Ausschuss für Küstenschutzwerke der DGEG und der HTG, 1993). These recommendations are mostly based on practical experience and the results of several case studies, which were conducted along the German coast in the past decades of beach nourishment (e.g. Dette and Gärtner 1987; Erchinger 1986, 1975; Erchinger and Tillmann 1992; Führböter et al. 1976, 1972; Führböter and Dette 1992; Kramer 1958). A more recent version of the recommendations exists (Ausschuss für Küstenschutzwerke der DGEG und der HTG 2007); however, the chapter about nourishments has not been updated since its original publication in the beginning of the 1990s. In a current research project (Interreg VB NSR: Building with Nature) an international group of coastal authorities from the North Sea region evaluates the technical design criteria for beach nourishments along their coastlines, aiming at the development of new design guidelines (Wilmink et al. 2017).

As marine sediment extraction is not only conducted in the course of beach nourishment projects but also for commercial purposes or for large infrastructure projects, e.g. land reclamation and port extensions, many studies and guidelines (sometimes issued or commissioned by the marine aggregate supply industry) have dealt with the impacts of dredging activities in the past decades. Specifically investigating the effects of the extraction of marine sediment on the marine ecosystem, the International Council for the Exploration of the Sea (ICES) has compiled recommendations and guidelines (Sutton and Boyd 2009) which are sought to be implemented in all OSPAR and HELCOM member countries. Several countries (e.g. the Netherlands, Belgium, UK) have formally adopted these guidelines or base their own marine sediment extraction guidelines on the ICES recommendations. The authors of the guidelines admit a lack of knowledge, especially concerning the long-term effects of sediment extraction. In order to improve the monitoring of dredging activities, some countries have introduced compulsory surveillance systems for dredging vessels. However, as not all OSPAR/HELCOM member countries collect comprehensive data in order to achieve transparency of their dredging activities, it is difficult to evaluate the success of the ICES recommendations.

\section{Practical assessment of environmental impacts}

The existing guidelines and recommendations mentioned above mainly provide qualitative advise, e.g. on the general need for an EIA, on monitoring and sampling duration and extent or on sample species. Based on the ICES guidelines 
Table 3 International comparison of the assessment of environmental impacts

Assessment of Environmental Impacts

Extraction Site Nourishment Site

\begin{tabular}{|c|c|c|c|c|c|c|}
\hline Country & $\begin{array}{l}\text { Requirements for } \\
\text { permission }\end{array}$ & $\begin{array}{l}\text { Environmental data } \\
\text { collected for } \\
\text { permission }\end{array}$ & $\begin{array}{l}\text { Monitoring after } \\
\text { permission }\end{array}$ & $\begin{array}{l}\text { Requirements for } \\
\text { permission }\end{array}$ & $\begin{array}{l}\text { Environmental data } \\
\text { collected for } \\
\text { permission }\end{array}$ & $\begin{array}{l}\text { Monitoring after } \\
\text { permission }\end{array}$ \\
\hline Germany & $\begin{array}{l}\text { - EIA required if } \\
\text { disturbed area }> \\
0.25 \mathrm{~km}^{2} \\
\text { - Always required: } \\
\text { Landscape } \\
\text { Conservation } \\
\text { Plan } \\
\text { - License issued by } \\
\text { responsible } \\
\text { (mining) } \\
\text { authority }\end{array}$ & $\begin{array}{l}\text { - Measurements and } \\
\text { data collection } \\
\text { during limited } \\
\text { time before } \\
\text { permission only } \\
\text { - Existing literature } \\
\text { and sediment } \\
\text { databases }\end{array}$ & $\begin{array}{l}\text { - Only geological } \\
\text { investigations to } \\
\text { assess quantity } \\
\text { and quality of } \\
\text { source material } \\
\text { - No ecological } \\
\text { assessment (only } \\
\text { within research } \\
\text { projects) }\end{array}$ & $\begin{array}{l}\text { - EIA requirement } \\
\text { assessed } \\
\text { individually } \\
\text { - Often only } \\
\text { Landscape } \\
\text { Conservation Plan } \\
\text { required } \\
\text { - License issued by } \\
\text { responsible } \\
\text { environmental } \\
\text { authority }\end{array}$ & $\begin{array}{l}\text { - Often the same data } \\
\text { base as for } \\
\text { extraction EIA } \\
\text { - Measurements and } \\
\text { data collection } \\
\text { during limited time } \\
\text { before permission } \\
\text { only } \\
\text { - Existing literature }\end{array}$ & $\begin{array}{l}\text { No (within research } \\
\text { projects only) }\end{array}$ \\
\hline Denmark & $\begin{array}{l}\text { - EIA always } \\
\text { required } \\
\text { - License issued by } \\
\text { Ministry for the } \\
\text { Environment }\end{array}$ & $\begin{array}{l}\text { Data collected by } \\
\text { Geological } \\
\text { Survey GEUS } \\
\text { (e.g. Seabed } \\
\text { Sediment Maps, } \\
\text { habitat maps) on }\end{array}$ & $\begin{array}{l}\text { Continuous } \\
\text { monitoring of } \\
\text { environmental } \\
\text { impacts is } \\
\text { compulsory }\end{array}$ & $\begin{array}{l}\text { - EIA requirement } \\
\text { assessed } \\
\text { individually } \\
\text { - License issued by } \\
\text { environmental } \\
\text { authority }\end{array}$ & $\begin{array}{l}\text { - Mandatory data } \\
\text { collection for sites } \\
\text { that require EIA } \\
\text { - Existing literature }\end{array}$ & $\begin{array}{l}\text { No (within research } \\
\text { projects only) }\end{array}$ \\
\hline
\end{tabular}

a regular basis

\begin{tabular}{|c|c|c|}
\hline Netherlands & $\begin{array}{l}\text { EIA required if } \\
\text { - Area }>5 \mathrm{~km}^{2} \text { or } \\
\text { - Volume }>10 \\
\text { million } \mathrm{m}^{3} \\
\text { License issued by } \\
\text { Ministry of } \\
\text { Infrastructure } \\
\text { and the } \\
\text { Environment }\end{array}$ & $\begin{array}{l}\text { - Continuous } \\
\text { collection of } \\
\text { measurements } \\
\text { and modelling } \\
\text { results based on } \\
\text { the sand } \\
\text { extraction } \\
\text { strategy } \\
\text { - Strategy is } \\
\text { renewed ca. } \\
\text { every } 5 \text { years }\end{array}$ \\
\hline
\end{tabular}

Belgium
EIA always
required to
extract sand
from pre-defined
extraction areas
- License issued by
Ministry of
Economy of
Flanders based
on advice from
the Minister of
the North Sea
Environment

- Compulsory environmental monitoring and evaluation campaign to assess the impacts

- Additional measures can be compulsory, based on findings
Spain

\footnotetext{
- Galicia,

Cantabria: EIA always required

- Other states: EIA required if volume $>3$ million $\mathrm{m}^{3}$
}

\begin{tabular}{|c|c|}
\hline $\begin{array}{l}\text { Biannual } \\
\text { monitoring } \\
\text { campaign by the } \\
\text { federal } \\
\text { government to } \\
\text { pre-defined } \\
\text { extraction areas } \\
\text { and reference 'no } \\
\text { extraction' zone }\end{array}$ & $\begin{array}{l}\text { Biannual } \\
\text { monitoring } \\
\text { campaign by the } \\
\text { federal } \\
\text { government to } \\
\text { pre-defined } \\
\text { extraction areas } \\
\text { and reference 'no } \\
\text { extraction' zone }\end{array}$ \\
\hline
\end{tabular}

No (within research projects/large-scale management schemes only, e.g. Zandmotor)

in the cross-shore profile)

- Not applicable for most sand nourishments, except for

Zandmotor and HPZ
EIA is required only - Separate monitoring No (within research once for strategic programme projects only) masterplans $\quad$ Existing literature

- Individual nourishments typically do not require an additional EIA

\footnotetext{
- Mostly only geological investigations to assess quantity \& quality of source material
}
EIA required if volume $>500,000$ according to the Spanish coastal regulation maps
No (within research
projects only)
po (within research
projects only)
- Mandatory data collection for sites that require EIA available


Table 3 (continued)

Assessment of Environmental Impacts

Extraction Site Nourishment Site

\begin{tabular}{lllllll}
\hline Country & $\begin{array}{l}\text { Requirements for } \\
\text { permission }\end{array}$ & $\begin{array}{l}\text { Environmental data } \\
\text { collected for } \\
\text { permission }\end{array}$ & $\begin{array}{l}\text { Monitoring after } \\
\text { permission }\end{array}$ & $\begin{array}{l}\text { Requirements for } \\
\text { permission }\end{array}$ & $\begin{array}{l}\text { Environmental data } \\
\text { collected for } \\
\text { permission }\end{array}$ & $\begin{array}{l}\text { Monitoring after } \\
\text { permission }\end{array}$ \\
\hline
\end{tabular}

\begin{tabular}{|c|c|c|c|c|c|c|}
\hline & & & $\begin{array}{l}\text { - Comprehensive } \\
\text { ecological } \\
\text { monitoring in } \\
\text { large extraction } \\
\text { areas only }\end{array}$ & & & \\
\hline $\begin{array}{c}\text { UK (England } \\
\text { \& Wales) }\end{array}$ & $\begin{array}{l}\text { - License (incl. } \\
\text { EIA) always } \\
\text { required for } \\
\text { extraction } \\
\text { - License reviewed } \\
\text { by MMO every } \\
5 \text { years }\end{array}$ & $\begin{array}{l}\text { - Baseline data from } \\
\text { RSMP (benthos } \\
\text { and sediment } \\
\text { parameters), } \\
\text { collected } \\
\text { 2014/2015 } \\
\text { - Good practice to } \\
\text { collect up-to-date } \\
\text { data }\end{array}$ & $\begin{array}{l}\text { - Monitoring } \\
\text { required for } \\
\text { MMO license } \\
\text { renewal } \\
\text { - After dredging } \\
\text { completed: Not } \\
\text { mandatory, but } \\
\text { license holders } \\
\text { are expected to } \\
\text { continue } \\
\text { environmental } \\
\text { monitoring }\end{array}$ & $\begin{array}{l}\text { - EIA requirement } \\
\text { assessed } \\
\text { individually } \\
\text { • EIA likely required } \\
\text { if area }>0.01 \mathrm{~km}^{2} \\
\text { or works are } \\
\text { "capable of altering } \\
\text { the coast" } \\
\text { - No EIA required for } \\
\text { "maintaining } \\
\text { coastal defence } \\
\text { works" } \\
\text { (re-nourishment, } \\
\text { recycling, } \\
\text { re-profiling) }\end{array}$ & $\begin{array}{l}\text { - Existing } \\
\text { databases/literature } \\
\text { - Good practice to } \\
\text { collect up-to-date } \\
\text { data on vegetation, } \\
\text { invertebrates, birds }\end{array}$ & $\begin{array}{l}\text { No (within research } \\
\text { projects/large-- } \\
\text { scale } \\
\text { management } \\
\text { schemes only, } \\
\text { e.g. Lincshore) }\end{array}$ \\
\hline USA & $\begin{array}{l}\text { - EIA always } \\
\text { required } \\
\text { - License issued by } \\
\text { USACE under } \\
\text { Clean Water Act } \\
\text { "Beneficial Use } \\
\text { of Dredged } \\
\text { Material" } \\
\text { Endangered } \\
\text { Species Act } \\
\text { (ESA) }\end{array}$ & $\begin{array}{l}\text { - Bathymetric \& } \\
\text { sub-bottom } \\
\text { surveys } \\
\text { - Sediment coring } \\
\text { and } \\
\text { surface surveys } \\
\text { - Optional } \\
\text { additional data, } \\
\text { like archaeology, } \\
\text { bathymetry, benthic } \\
\text { \& biological data } \\
\text { acquisition }\end{array}$ & $\begin{array}{l}\text { Only within } \\
\text { research projects }\end{array}$ & $\begin{array}{l}\text { - EIA/EA required } \\
\text { - License issued by } \\
\text { USACE under } \\
\text { Clean Water Act } \\
\text { "Beneficial Use of } \\
\text { Dredged Material" } \\
\text { - Nourishments in } \\
\text { navigable waters } \\
\text { require license } \\
\text { under River and } \\
\text { Harbor Act } \\
\text { - Endangered Species } \\
\text { Act (ESA) }\end{array}$ & $\begin{array}{l}\text { - Existing } \\
\text { databases/literature } \\
\text { - If data is not available } \\
\text { or project costs }> \\
\$ \text { US 400,000: } \\
\text { Collection of new } \\
\text { environmental data } \\
\text { (turbidity, benthic } \\
\text { fauna, fish, habitat } \\
\text { changes) } \\
\text { - Collected data } \\
\text { usually published in } \\
\text { public domain }\end{array}$ & $\begin{array}{l}\text { Only in exceptional } \\
\text { cases }\end{array}$ \\
\hline Australia & $\begin{array}{l}\text { Dependent on } \\
\text { Commonwealth } \\
\text { and state } \\
\text { legislature: } \\
\text { - preliminary } \\
\text { environmental } \\
\text { assessment } \\
\text { report } \\
\text { - environmental } \\
\text { assessment } \\
\text { requirements } \\
\text { determined by } \\
\text { Commonwealth } \\
\text { or State based on } \\
\text { project scope } \\
\text { - Mining license for } \\
\text { extraction }\end{array}$ & $\begin{array}{l}\text { Recommended } \\
\text { monitoring } \\
\text { during } \\
\text { construction } \\
\text { works: Marine } \\
\text { mammals, water } \\
\text { quality, sediment } \\
\text { quality }\end{array}$ & $\begin{array}{l}\text { Covered within: } \\
\text { - Statement of } \\
\text { commitment } \\
\text { - Environmental } \\
\text { risk analysis } \\
\text { - Environmental } \\
\text { management plan } \\
\text { Implemented in } \\
\text { large-scale } \\
\text { projects (e.g. } \\
\text { Tweed River } \\
\text { Sand Bypassing } \\
\text { Project) }\end{array}$ & $\begin{array}{l}\text { Depending on project } \\
\text { size and location: } \\
\text { Review of } \\
\text { Environmental } \\
\text { Effects, Statement } \\
\text { of Environmental } \\
\text { Effects or } \\
\text { Environmental } \\
\text { Impact Statement, } \\
\text { Coastal Council } \\
\text { proponent and } \\
\text { approval authority } \\
\text { at the same time }\end{array}$ & $\begin{array}{l}\text { Sand quality testing } \\
\text { only, no ecological } \\
\text { monitoring }\end{array}$ & $\begin{array}{l}\text { No, within } \\
\text { large-scale } \\
\text { projects only } \\
\text { (e.g. Tweed } \\
\text { River } \\
\text { Sand Bypassing } \\
\text { Project) }\end{array}$ \\
\hline
\end{tabular}


several responsible (coastal) authorities and policy makers have implemented corresponding regulations for marine sediment extraction in national law. These formal regulations for environmental monitoring that apply for sand extraction and sand nourishment activities as well as the state of the practice in the different countries are described in the following section and summarized in Table 3.

\section{Germany}

Based on the EU EIA Directive, an EIA is required for every activity in Germany that is expected to have a significant impact on the environment. For all activities that affect the landscape and the environment in any way, a so-called Landscape Conservation Plan (LCP, Landschaftspflegerischer Begleitplan) has to be provided. Similar to the EIA report, the LCP describes the elements of the environment and the expected impacts - however, the elements "humans" and "cultural heritage" are omitted and sometimes covered in complementary Social Impact Assessments (SIA). In contrast to the EIA report, which only contains recommendations for the mitigation of impacts, the LCP can specify mitigation or compensation measures and is legally binding.

According to German mining law, every proposed sediment extraction project that is i) larger than $25 \mathrm{ha}\left(0.25 \mathrm{~km}^{2}\right)$ or ii) located in a nature protection area (marine protected area/MPA) or an area protected under the EU Habitats Directive requires an EIA and an accompanying LCP. Aggregates for nourishments are extracted from dedicated offshore borrow areas, which are licensed for about 1520 years for this purpose only. An accompanying, regular environmental monitoring during the duration of the extraction activities is recommended in the EIA (for documentation purposes) but is not a prerequisite for the ongoing dredging operation. However, observed negative environmental impacts could require e.g. an adjustment of the dredging technique.

Nourishments, i.e. dumping activities at the shore or shoreface are screened for their EIA requirement individually, but usually require only a Landscape Conservation Plan, as no significant impact on the environment is expected. If the affected site is located in an MPA, additional documentation has to be submitted for the licensing process. Both EIA reports for the extraction and the nourishment activity are usually based on the same ecological datasets or existing studies. The reference state of all environmental elements has to be investigated at various locations in and around the area which is likely to be affected by the activity. Although useful for conclusions about the affected environmental element, it is not mandatory to investigate e.g. species abundance during different seasons. Several EIA studies acknowledge a gap of knowledge and recommend long-term monitoring of ecological processes in the vicinity of extraction and nourishment sites. However, a subsequent monitoring after the extraction or nourishment activity is not mandatory for the executing body and usually omitted.

\section{Denmark}

In Denmark an EIA is required for the extraction site prior to any marine aggregate operations (Miljø- og Fødevareministeriet 2018). The license for aggregate extraction is issued by the Danish Ministry of the Environment (Miljøministeriet); the required environmental data, e.g. seabed sediment maps, is collected by the Geological Survey of Denmark and Greenland (Danmarks og Grønlands Geologiske Undersøgelse, GEUS) on a regular basis. After the extraction license is issued, the continuous monitoring of environmental impacts at the borrow site is compulsory.

To assess the need for an EIA at the nourishment site, an individual screening is conducted (Miljø-og Fødevareministeriet 2018). If required, the EIA is commissioned by the coastal communities and evaluated by the Danish Coastal Authority (Kystdirektoratet). An ecological monitoring of the nourishment site after the permission is not mandatory and only conducted within research projects.

\section{The Netherlands}

In the Netherlands a permit of the Ministry of Infrastructure and the Environment is required to extract marine sand between the $-20 \mathrm{~m}$ depth contour and the border of the 12 mile zone, excluding MPAs determined as Natura 2000 sites. An EIA is necessary if i) the planned extraction area is larger than $500 \mathrm{ha}\left(5 \mathrm{~km}^{2}\right)$ or ii) the extraction volume is larger than 10 million $\mathrm{m}^{3}$ (Ebbens 2016; Walker et al. 2016). In the EIA report the MEFA (most environmentally friendly alternative) solution, e.g. minimum impact option for a project, is selected and documented. A compulsory MEP (monitoring and evaluation programme) is part of the permit and serves to evaluate the actual environmental impacts of the extraction (Rozemeijer et al. 2013). In case of discrepancies, legally binding mitigation measures can be demanded by the Ministry. Recent EIAs and MEPs (e.g. van Duin et al. 2017) are based on findings of previous EIA/MEP studies.

At the nourishment location an EIA has to be conducted when i) a primary coastal defence structure is adjusted (e.g. a sea dike) or ii) a primary coastal defence structure is adapted over a longshore length of $\geq 5 \mathrm{~km}$ with related changes of $\geq 250 \mathrm{~m}^{3} / \mathrm{m}$ in the cross-shore profile (Karman et al. 2013). Hence, regular re-nourishments are usually excluded from the EIA requirement, but an EIA had to be performed for the recent mega-nourishments (Fiselier 2010; Karman et al. 2013). No compulsory monitoring programs are part of 
the legal procedures. Instead, additional individual monitoring programmes were initiated within research projects (e.g. project 'ecological nourishing' in 2009 (Holzhauer et al. 2009), based on recommendations of Baptist et al. (2009), project NatureCoast in 2011 and project $H P Z$ in 2015).

\section{Belgium}

Based on a study by Schotte (1999), the Belgian region of Flanders has allocated several control zones in which marine sediment can be extracted (Federale Overheidsdienst 2014). An EIA has to be prepared and submitted in order to apply for an extraction permit (IMDC 2010; van Lancker et al. 2015). In the control zones a maximum volume of 15 million $\mathrm{m}^{3}$ can be extracted over a period of 5 years; the maximum bed-level decrease is set to $5 \mathrm{~m}$. For the Masterplan for Coastal Safety an additional control zone has been allocated for the extraction of 35 million $\mathrm{m}^{3}$ over a period of 10 years. Environmental impacts are mostly based on previous monitoring studies (Derweduwen et al. 2009; De Backer et al. 2010) and the EIA reports recommend future monitoring efforts to conclude on environmental impacts. However, these efforts are not a compulsory part of the subsequent extraction activity. Instead, a biannual monitoring campaign is carried out by the Flemish government (De Backer et al. 2010). A part of the monitoring is focussed on an allocated reference zone in which no extraction is allowed.

The Masterplan for Coastal Safety requests a so-called plan-EIA for the nourishment locations (Afdeling Kust 2018). For each activity in the masterplan, possible solutions are ordered according to their environmental impact. In addition, the individual projects in the masterplan require a project-EIA. However, projects in the category to 'mitigate coastal erosion' are eligible for exemption from the project-EIA, which applied to all the nourishments placed along the Belgian coast between 2011 and 2013 (Bernaert 2013). Individual reports for these nourishments (e.g. Tritel 2011a, b, c), which were based on literature (Speybroeck et al. 2004; Vanden Eede 2013; Vanden Eede et al. 2014), have found no significant effects on the environment, also due to additional mitigation measures. As a result, no mandatory monitoring was required.

\section{Spain}

According to the Spanish Shores Act beach nourishments are the only activities which allow marine aggregate extraction from the Spanish continental shelf. All sediment extractions exceeding 3 million $\mathrm{m}^{3}$ require a regulated EIA according to the EU EIA Directive, while the states of Galicia, Cantabria and the Basque Country demand a regulated EIA for all (also smaller) extractions (Sutton and Boyd 2009). According to
Sutton and Boyd (2009), comprehensive environmental monitoring studies are conducted in large extraction areas. The recommendations issued by ICES have been translated into Spanish and have been distributed to the responsible authorities (Buceta Miller et al. 2004).

At the shore, nourishment volumes exceeding $500,000 \mathrm{~m}^{3}$ (per project) require an EIA according to the EU EIA Directive including the collection of environmental data (Ley 21/2013 2013). However, as many nourishment projects in Spain do not exceed this limit (Muñoz-Perez et al. 2001; Hanson et al. 2002), there are no environmental assessments for many Spanish beaches. In addition, Herrera et al. (2010) note that - even for beaches where an EIA was mandatory long-term data about the environmental elements is often not available. After the nourishment activity is completed, no subsequent environmental monitoring is conducted, which is why long-term environmental impacts cannot be assessed. Nevertheless, Hanson et al. (2002) state that during nourishment design environmental aspects seem to be of higher importance than engineering aspects.

\section{UK: England and Wales}

Material for nourishments in England and Wales mostly originates from licensed marine aggregate extraction areas on the British continental shelf. These (commercial) extraction areas require a license from the Marine Management Organisation (MMO) that administers the mineral resources owned by The Crown Estate. A large part of the marine gravel and sand is used in the British construction industry, while in 2006 only around $17 \%$ of marine material was used for beach nourishments (Highley et al. 2007). The licensing process requires a site-specific EIA. On a wider scale, a series of Marine Aggregate Regional Environmental Assessments (MAREAs) has been conducted to investigate the cumulative effects of several extraction areas in the main dredging areas (BMAPA and The Crown Estate 2017). For any environmental monitoring conducted within the licensing process, the Regional Seabed Monitoring Programme (RSMP) is used as baseline: The RSMP is a comprehensive dataset of sediment composition and benthos communities along the British continental shelf which was completed in 2015 (The Crown Estate 2017). Once granted, a marine license allows sediment extraction for up to 15 years; however, the license (and possible monitoring and mitigation requirements) is reviewed by the MMO every 5 years. A subsequent environmental monitoring in the area is compulsory and the results have to be submitted for the license renewal. After dredging at a site is completed (e.g. after the license has expired), subsequent environmental monitoring is not mandatory, but considered good practice (BMAPA and The Crown Estate 2017). To avoid sediment plumes during dredging and subsequent negative effects on the environment, the screening of dredged 
material (i.e. the removal and deposition of unwanted grainsize fractions from the dredging vessel) may be restricted in certain areas (Moses and Williams 2008; BMAPA and The Crown Estate 2017).

At the coast new sand nourishments that either i) exceed an area of $1 \mathrm{ha}\left(0.01 \mathrm{~km}^{2}\right)$ or ii) are capable of altering the coast are "likely" to require an EIA, whereas maintenance works, such as re-nourishing, scraping or recycling are less likely (Rogers et al. 2010). Similar to other countries, large-scale beach management schemes in England and Wales (e.g. Lincshore) may include an accompanying environmental monitoring programme to investigate long-term environmental effects. In the early phases of the Lincshore project (19962001) environmental data were collected tri-annually, in spring, summer and autumn of each year. The environmental monitoring was reduced to an annual monitoring when an apparent relation between nourishment and benthic community abundance and composition could be excluded (Environment Agency 2009). However, many smaller maintenance works - on local scales or as part of larger schemes have been conducted without documentation or environmental monitoring (Moses and Williams 2008). Baseline data for nourishment activities can be gathered from several data sources, e.g. Natural England or the National Biodiversity Network, which contains information about invertebrate of fish species. Rogers et al. (2010) acknowledge that existing databases do not cover all coastal areas and/or might not be up to date. It is therefore generally considered good practice to collect up-to-date data on vegetation, invertebrates and birds in the affected area.

\section{USA}

In the USA the National Environmental Policy Act (NEPA) stipulates that an Environmental Assessment (EA) has to be carried out as part of the permit for sediment extraction or nourishment activities. Additionally, nourishment or sand removal must be approved by the USACE under the Clean Water Act (Section 404) "Beneficial Use of Dredged Material". The EAs for beach nourishment projects of federal interest are prepared by the USACE with advice from the Environmental Protection Agency EPA (US EPA, USACE, 2007), while the EA for projects of non-federal interest have to be submitted by the project owners. In the EA the activities' impact on water and air quality as well as influences on the various habitats (sea, dune, beach) and organisms are evaluated. In addition, the Endangered Species Act (ESA) is relevant to investigate whether any endangered species are affected by the activity. The environmental assessments are often based on existing data from extensive biological monitoring campaigns at many frequently nourished sites in states such as Florida, North Carolina and New Jersey (e.g. Burlas et al. 2001). Data collected as part of the EA are usually made accessible in the public domain. If comprehensive environmental data is not available, new monitoring campaigns are conducted. Once the local physical and ecological processes are understood or ongoing monitoring shows quick recovery rates, the monitoring requirements can be relaxed for future projects to minimize monitoring efforts and reduce project costs (Bergquist and Crowe 2009; Rosov et al. 2016). Several states request a mandatory monitoring under certain circumstances: In Florida, for example, monitoring of benthos should be carried out if the seafloor that might be affected by the nourishment consists of hard substrates (Kosmynin et al. 2016).

Extensive measures for ecological monitoring are proposed in the "Environmental Engineering for Coastal Shore Protection" handbook (US Army Corps of Engineers 1989), which recommends turbidity measurements, data collection on fish and benthic fauna, and an analysis of habitat changes. As part of a permit under the Clean Water Act (Section 404), biological monitoring can also be imposed as a mitigation measure.

\section{Australia}

Due to the structure of responsibilities within coastal management in Australia, environmental considerations of nourishments and associated extraction works are likewise affected by Commonwealth as well as state legislature (Harvey and Caton 2010). The Environment Protection and Biodiversity Conservation Act (EPBC) regulates all matters falling under national jurisdiction which are relevant for nourishment projects. These include world heritage properties, national heritage places, wetlands of international importance, listed threatened species and ecological communities, migratory species protected by international agreements, Commonwealth marine areas and the Great Barrier Reef Marine Park. Any sediment extraction within a limit of 3 nautical miles from the coast falls under state legislation (AECOM 2010). If both state and national laws are affected, bilateral agreements are in place and state agencies will act on behalf of both (The State of Victoria 2006). A first step within the project approval process is the referral to the Australian Minister for Environment and Energy or the state executive, which differs in its denomination from state to state. The national or state representative will then determine if approval is necessary and which extent the assessment and potential monitoring will have depending on the project scope. This may include a statement of commitments signed by the project proponents covering mitigation measures, consultation requirements throughout the project as well as an environmental risk assessment for the individual project phases (e.g. AECOM 2010). Generally, continuous consultation of different stakeholders and agencies is an integral part of the procedure. For the construction phase an environmental management plan is 
required. In Australia special attention is paid to offshore sand mining and sand extraction has to be approved under environment legislature as well as state mining laws. In New South Wales recent scoping studies for the extraction of sand from offshore sources have pointed out that the state government does not support offshore sand mining under the Offshore Minerals Act (e.g. AECOM 2010, Patterson Britton \& Partners Pty Ltd. 2006). Previous mining endeavours have been opposed due to environmental concerns by the government and local stakeholders.

Information on environmental considerations for the placement of sand at the beach is scarce. Generally, approval under the state's coastal management act is required (Patterson Britton \& Partners Pty Ltd. 2006). In case of beach scraping, the local government authority is both the proponent and approval authority. Required investigations depend on project size and location. They range from a Review of Environmental Factors (REF) or a Statement of Environmental Effects (SEE) to an environmental/species impact statement and/or a permit for destruction of marine vegetation (Carley and Cox 2017). This policy is supported by site-specific research at Australian beaches (e.g. Schlacher et al. 2012, Jones et al. 2008).

\section{Discussion}

\section{Strategic framework and current practice}

In Belgium, Denmark, Germany and the Netherlands beach nourishments are included in long-term masterplans for coastal protection. All four countries include regular (re-)nourishments to maintain the current shoreline in the short-term, with many erosion hot spots being re-nourished every year. Considering the large nourishment volumes and the relatively short coastal stretches that are nourished in Belgium, the Netherlands and the German island of Sylt, the nourishment densities along these parts of the North Sea coast are very high. It is remarkable that the Dutch national authority Rijkswaterstaat, which is responsible for coastal protection in the Netherlands, also manages inland waterways and estuaries. Hence, Rijkswaterstaat is able to incorporate the complete aquatic (fluvial, estuarine and coastal) system into their sediment management and coastal protection, without having to overcome hurdles that might exist between different authorities. In stark contrast to the North Sea countries, Spain has no national long-term strategy and nourishments are mostly remedial measures. Albeit the Spanish government has intended to implement the ICZM guidelines, Ariza (2011) names the "lack of adequate institutions for managing the coast" as the biggest obstacle in reaching a successful coastal management strategy. Certainly a country's size and administration play an important role for the development and implementation of national strategies: While a national coastal management strategy may be easily implemented in small countries like the Netherlands or Denmark, more regional approaches are required in larger countries (with long coastlines) like Spain, the USA and Australia. Clear legal frameworks and cooperation across administrative levels form the basis for the successful implementation of a national management strategy.

Many countries or regions which have implemented longterm coastal management strategies rely on a frequent renourishment with small sand volumes (Denmark, Germany, Netherlands, Belgium, US East Coast). Verhagen (1992) and Walvin and Mickovski (2015) list the visibility of such regular nourishments as an important factor for the public perception, as beach goers are able to see how their taxes are invested. However, along with other studies (e.g. Brown et al. 2016; Stive et al. 2013) Walvin and Mickovski (2015) conclude that mega-nourishments (like the Zandmotor) are a more sustainable option for the future, as they only disturb the natural environment once, but i) allow longer timescales for ecosystem recovery and ii) have several socio-economic benefits (e.g. increased beach amenity, long-term cost efficiency etc.). It has to be noted that a mega-nourishment can have large-scale effects on the sediment budget (i.e. across sediment cells, regional or even national borders) and thus requires a large-scale management scheme. The implementation in countries where nourishment activities are managed on a regional scale (e.g. per state in Germany, per coastal cell in England/Wales) might prove difficult (e.g. Vikolainen et al. 2017), as current governance does not facilitate actions across administrative borders.

\section{Differences in environmental monitoring practice and legislation}

The comparison of the EIA criteria in the countries investigated for this study (Table 3) shows several striking differences. As summarized in Table 2, marine aggregates are the primary material source for beach nourishments in most countries (except for Australia and several US projects). In some regions (like England, Wales and several Spanish states) an EIA is mandatory for every marine sediment extraction activity, regardless of size or volume. Other nations have (legally) established size limits for extraction activities that can be carried out without an EIA; however, these criteria diverge considerably, with size limits ranging from $0.25 \mathrm{~km}^{2}$ (Germany) to $5 \mathrm{~km}^{2}$ (Netherlands, cf. Table 3). After the extraction is permitted, a subsequent environmental monitoring is mandatory in Denmark, the Netherlands, Belgium, England and Wales, and large extraction areas in Spain. In England and Wales the license renewal (required every 5 years) depends on the outcome of this monitoring; in the Netherlands the evaluation of the subsequent monitoring can determine 
additional measures to mitigate further environmental impacts. A regular environmental monitoring of the borrow area and a re-evaluation/renewal of extraction licenses seems reasonable to 1) document negative changes and 2) allow stopping the activities in case of severe environmental impacts. In many other cases the environmental changes are merely documented to fill knowledge gaps or investigated within specially dedicated research projects, but the dredging activities are unlikely to be stopped within the licensing period (which in some cases covers several decades).

At the nourishment site the differences in the EIA criteria are even more pronounced. While some countries request an EIA (or similar environmental assessment) for every (new) nourishment activity, Spain allows projects with a volume below $500,000 \mathrm{~m}^{3}$ to be conducted without environmental assessment (Table 3). In the Netherlands a nourishment of less than $5 \mathrm{~km}$ coastal length with a cross-shore coverage below $250 \mathrm{~m}^{3} / \mathrm{m}$ (i.e. below an effective volume of 1.25 million $\mathrm{m}^{3}$ ) does not require an EIA. Despite the large annual nourishment volumes in Spain and the Netherlands (10 and 12 million $\mathrm{m}^{3}$, Table 2), most individual projects (except for the meganourishments in NL) lie below these criteria and thus evade a mandatory EIA (cf. e.g. Gracia et al. 2013; MuñozPerez et al. 2001 for nourishment volumes in Spain). In countries with high re-nourishment rates (e.g. Germany, Denmark, Netherlands, Belgium, England and Wales) these "maintenance nourishments" do not require an additional EIA every time new material is placed on the same coastal stretch. This is one of the main reasons why a consecutive monitoring of the environment is often not conducted at sites which are frequently re-nourished - and long-term impacts might go unnoticed.

An EIA for a proposed project is required if significant environmental impacts are to be expected. The large differences in EIA criteria (even within the EU) show how the perception of significant environmental impacts varies in different countries. The differences likely stem from the fact that, with the current (limited) state of knowledge, the spatial and temporal scale of the environmental impacts of an extraction or nourishment activity cannot be reliably predicted. Thus, the environmental impacts of the activities cannot be fully taken into account in national and local nourishment practice, and the ecosystem approach cannot be successfully implemented. Considering this lack of knowledge about the actual environmental impacts, the size criteria in the environmental legislation policies seem to be chosen haphazardly. The long-term environmental data, which exists for large extraction areas in some countries, should be used to develop ecologically sustainable strategies for sediment extraction, which could then be transferred to other countries. The outcomes of the few long-term environmental monitoring campaigns in the framework of large-scale nourishment schemes (Zandmotor, HPZ, Lincshore) will have to prove if and how a frequent monitoring of nourishment sites (and the establishment of a regular re-evaluation and license renewal) should become compulsory for all nourishment activities. In any case, knowledge transfer (between regions or countries) of research results and practical experiences is crucial for the development of a comprehensive, sustainable coastal management strategy.

It must be noted that environmental monitoring campaigns are expensive and laborious activities. Thus, if the available monitoring data shows - with a certain confidence - insignificant impacts or high recovery rates of key species, regular monitoring activities cease. The results are then usually transferred to other sites with similar environmental conditions in order to save time and labour during the EIA procedure.

\section{Limits of EIA as tool}

Although most EIAs coping with extraction or dumping of aggregates in nourishment activities acknowledge several significant impacts (e.g. benthic communities dying off and recovery rates of many years or even decades), these conclusions usually do not impede the permit. Potential negative long-term consequences of extraction or nourishment activities are oftentimes tolerated. It is interesting to note that estimated benthos recovery rates of several years are accepted for proposed projects with a re-nourishment rate of one to two years. There is only one planned nourishment project known to the authors that was not permitted due to environmental (and social) concerns expressed by the public (Dean 2009). In the case in question the too fine borrow material would have significantly increased suspended sediment concentrations in the near-shore area and, upon settlement, endangered the local hard-bottom communities. Based on the expected environmental impacts, beach users and local communities successfully objected the project during the public participation of the EIA process and a permit was not issued by the responsible authority.

By listing mitigation measures (e.g. limiting the activities to certain months of the year, usage of specific equipment or techniques) an EIA can minimize the environmental impact of an activity. In addition, compensation measures can be ordered - however, a newly created habitat (e.g. wetlands or dune systems) might not be able to accommodate the same communities that were disrupted by a nourishment activity. The impact that the removal of a certain species might have on a local ecosystem is not reversed by the compensation measure in a different part of the coastal zone. Therefore, compensation measures can rather be labelled as a sound trade-off to enable nourishments at one site while enhancing the ecosystem at another site. It should also be noted that space for compensation measures is often not available and monetary compensation is instead paid to the responsible state. 
In addition the literature review and assessment of policy documents has shown that EIAs, when mandatory, can vary significantly in extent, e.g. regarding the spatial and temporal extent of direct ecological measurements or cited literature. While for example one EIA for a proposed extraction area in the North Sea included new data from monthly fly-overs (over the course of one year) to evaluate the abundance of marine mammals, the EIA for another proposed extraction area in the Baltic Sea instead referred to the observations in existing literature, some of them 50 years old. Large differences between EIA reports for beach nourishments have also been noted by other authors (Peterson and Bishop 2005; Bergquist and Crowe 2009) who attribute these to the lack of peerreview and inconsistencies in monitoring strategies and data analyses, amongst others. Hughes (1998) notes that some project planners view the EIA as a "necessary evil" rather than a valuable tool for robust decision-making that should safeguard or enhance the environment. Several studies have questioned if the EIA is failing to meet its original purpose (Peterson and Bishop 2005; Jay et al. 2007; Jha-Thakur and Fischer 2016; Fonseca et al. 2017; Roos et al. 2020). Many EIA reports on beach nourishment projects are not peer-reviewed and hence part of the grey literature only. Subsequently, possible flaws in methodology and interpretation are not corrected, which might affect the performance of the EIA as a regulating tool and subsequently the state of the environment in the long term. Bergquist and Crowe (2009) note that monitoring strategies and statistical methods in EIAs for nourishment projects in South Carolina were inconsistent over time, as the focus shifted to other species or statistical methods developed. This impedes the comparison of the large number of existing datasets. In addition, basic project information is often missing from the reports. For most countries that are covered in this study, it was difficult to find comprehensive information about previous nourishment activities, EIA documents and collected monitoring data. Both for practitioners and academic research there is great potential in the existing datasets from environmental monitoring campaigns. Jha-Thakur and Fischer (2016) call for a "collaborative approach amongst practitioners and academics" to close knowledge gaps, avoid a misunderstanding of the EIA regulations and improve the monitoring process. However, if the monitoring data cannot be accessed and used for further studies, the full potential cannot be exploited. Pooling and publishing monitoring datasets as part of the EIA procedure would be a valuable step towards a collaborative approach.

With regard to beach nourishment practice, the EIA procedure often provides a false sense of ecological sustainability for decision makers, who assume that nourishments are an environmentally friendly solution for coastal protection, once the permission has been granted. The same impression is subsequently perceived by the public, who often favours soft nourishment activities over hard coastal protection.

\section{Evaluating the sustainability of beach nourishments}

Within the coastal engineering community, beach nourishments are widely categorized as soft coastal protection measure, since only natural aggregates (i.e. sand) are dredged and transferred within the same coastal shelf system. While enhancing the level of coastal protection, they are also considered to sustain the natural environment. In recent decades, beach nourishments have proven capable of mitigating erosive processes on receding shoreline and have been useful to avoid the construction of new hard coastal protection. Subsequently, it is common understanding and current practice of many coastal authorities in the developed world that nourishments have outdated hard coastal protection infrastructure to mitigate coastal erosion, the latter having been deemed to deteriorate ecosystems and their services.

However, the large uncertainties regarding the environmental impacts (on small and large scale as well as in the short and long term) and the lack of robust recovery/refill predictions challenge the assumption that beach nourishments are a sustainable method to mitigate coastal erosion. The extraction of raw material from the ocean is unsustainable per se, as the aggregates are extracted at a higher rate than they are naturally reproduced. Refilling of an extraction site can only occur if material is available. To support the recovery of the local ecosystem, De Jong et al. (2016) have proposed ecosystembased design rules: The maximum extraction depth is chosen according to the expected bed shear-stress inside the extraction pit. This 'ecological landscaping' approach would facilitate the (re-)settlement of certain (native) target species. The current best practice in many regions to frequently nourish large stretches of coastline (e.g. along the North Sea coast or the US East Coast) requires vast amounts of compatible borrow material. Ongoing debates about limited sediment resources and cost effectiveness (e.g. Moses and Williams 2008; Parkinson and Ogurcak 2018; Velegrakis et al. 2010) are appropriate, as marine sediment is not only used for coastal protection, but in many countries also mined (and exported) for construction and land reclamation projects (e.g. Peduzzi 2014; The Crown Estate 2017). Following water resources, sand and gravel represent the second highest volume of raw material extracted on earth (Peduzzi 2014). Required sediment volumes for coastal protection are likely to increase in the next decades, as erosion is about to become more severe with rising sea levels and collateral effects. Parkinson and Ogurcak (2018) note that beach nourishments are not a sustainable method to mitigate climate-change induced coastal erosion in the long term when all factors are considered (which had not been done in previous studies). If the availability of 
compatible sediment, construction costs, the vulnerability of other coastal areas (e.g. back barriers, estuaries etc.), and environmental impacts are included, beach nourishments prove to be less cost-effective and sustainable than previous studies had assumed. Parkinson and Ogurcak (2018) as well as Moses and Williams (2008) conclude that beach nourishment can thus only be an interim strategy before a long-term strategy will have to be developed which, according to Parkinson and Ogurcak (2018), will likely include the managed retreat from the shorelines of developed countries. It must be noted that the review at hand does not consider the economic aspects of beach nourishment, which is out of the scope of this study.

In another recent study Armstrong and Lazarus (2019) describe that decades of beach nourishments along the US East Coast have effectively "masked" the large-scale coastal erosion due to sea-level rise. The authors conclude that beach nourishment projects have long since "geoengineered" the US coastline (albeit not on purpose), with nourishment projects along the coast also feeding adjoining coastal stretches. Instead of an intentional mega-nourishment, the continuous nourishment of selected beaches has cumulatively reversed the erosional trend. It is likely that similar effects can be found in other frequently nourished regions, e.g. the North Sea. This observation is supported by a global-scale assessment by Luijendijk et al. (2018), who used optical satellite images to investigate the occurrence of sandy beaches and rates of shoreline change over four decades. Focusing on a number of erosion/accretion hotspots around the world, the authors tried to attribute the local shoreline changes to natural vs. human drivers (e.g. sand mining or coastal engineering). The study shows that, despite sea-level rise, the majority of sandy shorelines are accreting or stable, a finding which was attributed to the stabilising effect of nourishment activities.

The observations from the studies mentioned above underline that cumulative, large-scale morphological effects cannot (yet) be properly anticipated in models or environmental impact assessments. In addition, the observed development further hinders the definition of a "baseline" or native environmental status at the coast, i.e. at the nourishment site. Considering the EIA procedure (cf. The environmental impact assessment), these striking anthropogenic impacts have significantly affected the nativeness of the environment, as a factor for the environmental impact assessment, over many years. It is to be expected that recent baseline studies at proposed nourishment sites in developed coastal regions are already biased by anthropogenic impacts. Similarly, efforts to reach or maintain "Good Environmental Status" (cf. the EU's Marine Strategy Framework Directive, e.g. descriptors 1 "Biodiversity", 6 "Sea-floor integrity" and 7 "Hydrographical conditions") do not consider the original, "native" environment, but an anthropogenic baseline that has already been shifted by human activities in recent decades.

\section{Conclusions}

This study elaborates on the differences in beach nourishment strategies and the accompanying environmental monitoring at the extraction and nourishment sites in a number of European countries, the USA and Australia. The review shows large international dissimilarities, which complicate the implementation of a common ecosystem approach to management. Based on the above review, the following conclusions can be drawn:

- Beach nourishments are widely used to counter-act potential erosion and have replaced hard coastal protection measures in many areas. They can be used to create or restore sandy habitat where it had previously been diminished by hard coastal protection measures, thus enhancing the coastal ecosystem. Marine sediment extraction and placement in the beach profile must, however, be regarded as disturbances of the environment.

- Many long-term effects of beach nourishments and marine sediment extraction are still not fully understood. Nevertheless, licensing authorities usually permit frequent nourishments which are capable to alter the coastline in the long term. Decade-long, reoccurring nourishment activities may potentially (and inadvertently) geoengineer large stretches of coastline and thus affect the coastal ecosystem.

- EIAs, which are required for all sediment extraction activities and most new nourishment activities, might be limited in their capability to estimate and control damage to the marine ecosystem. As long-term effects are not well understood today (due to a lack of comprehensive datasets and process understanding), the credibility of predictions about future developments (e.g. recovery rates of benthic organisms and long-term impacts on predatory species) is debatable.

- The documentation of subsequent environmental impacts after the permit for extraction/nourishment is essential to understand the ongoing physical (hydro- and morphodynamic) and biological processes. A regular re-evaluation of environmental impacts and possible withdrawal of an existing permit in case of severe impacts could ensure a more sustainable development of the coastline.

- Public databases of monitoring data from EIAs related to nourishment projects would a valuable resource for researchers and engineers, which might improve the understanding of positive and negative impacts of sediment extraction and nourishment activities.

- The initial, native environmental status, which is assessed before the start of a dredging or nourishment activity, is an anthropogenic baseline, which has already been altered by human activities for many decades. In several cases, observed shoreline accretion can likely be attributed to the large-scale, cumulative effects of decades of nourishment activities.

-While this study focuses on selected developed countries only, it should be noted that coastal erosion problems exist in many countries around the world. Some regions experience 
severe problems due to a lack of coastal management strategies combined with (illegal) sand mining along their sandy coastlines or in tributary rivers draining into the sea. As the deterioration of the coastal ecosystem affects the livelihood of people around the world, all countries should aim at the sustainable development of their coasts (cf. UN Sustainable Development Goals 14: Life below water).

Supplementary Information The online version contains supplementary material available at https://doi.org/10.1007/s11852-021-00801-y.

Acknowledgments This study has been funded by the German Federal Ministry of Education and Research (BMBF) through the project STENCIL (contract no. 03F0761). The authors acknowledge input from the Danish Coastal Authority (Kystdirektoratet) and Prof. Vicente Gracia (Universitat Politècnica de Catalunya) as well as feedback from participants of the 36th ICCE 2018 in Baltimore, USA.

Author contributions FS, RG, CG, FM and JW conducted the literature search and drafted the results section. FS wrote the introduction, methods, discussion and conclusions. HCH, TS, SS and HS conceptualized the study; HCH, TS, SS, NG and HS critically revised the manuscript. All authors commented on previous versions of the manuscript and approved the final version

Funding Open Access funding enabled and organized by Projekt DEAL.

\section{Compliance with ethical standards}

Declarations of interest The authors declare that they have no conflict of interest.

Open Access This article is licensed under a Creative Commons Attribution 4.0 International License, which permits use, sharing, adaptation, distribution and reproduction in any medium or format, as long as you give appropriate credit to the original author(s) and the source, provide a link to the Creative Commons licence, and indicate if changes were made. The images or other third party material in this article are included in the article's Creative Commons licence, unless indicated otherwise in a credit line to the material. If material is not included in the article's Creative Commons licence and your intended use is not permitted by statutory regulation or exceeds the permitted use, you will need to obtain permission directly from the copyright holder. To view a copy of this licence, visit http://creativecommons.org/licenses/by/4.0/.

\section{References}

AECOM (2010) Beach sand nourishment scoping study - maintaining Sydney's beach amenity against climate Change Sea level rise, Sydney

Afdeling Kust (2018) Masterplan Kustveiligheid. Visited in 11-2018

Ariza E (2011) An analysis of beach management framework in Spain. Study case: the Catalonian coast. J Coast Conserv 15:445-455. https://doi.org/10.1007/s11852-010-0135-y

Armstrong SB, Lazarus ED (2019) Masked shoreline erosion at large spatial scales as a collective effect of beach nourishment. https:// doi.org/10.1029/2018EF001070

ASBPA (2017) National Beach Nourishment Database. https://gim2. aptim.com/ASBPANationwideRenourishment/.
Ausschuss für Küstenschutzwerke der DGEG und der HTG (1993) Empfehlungen D. Sandaufspülungen als Küstenschutz. Die Küste 55 EAK:283-351

Ausschuss für Küstenschutzwerke der DGEG und der HTG (2007) EAK 2002. Empfehlungen für die Ausführung von Küstenschutzwerken, Korrigiert. KFKI, Hamburg

Baptist MJ, Leopold MF (2009) The effects of shoreface nourishments on Spisula and scoters in the Netherlands. Mar Environ Res 68:1-11. https://doi.org/10.1016/j.marenvres.2009.03.003

Baptist MJ, Tamis JE, Borsje BW, van der Werf JJ (2009) Review of the geomorphological, benthic ecological and biogeomorphological effects of nourishments on the shoreface and surf zone of the Dutch coast. IMARES C113/08, Deltares Z4582.50

Barragán Muñoz JM (2010) Coastal management and public policy in Spain. Ocean Coast Manag 53:209-217. https://doi.org/10.1016/j. ocecoaman.2010.04.006

Bell JJ, Mcgrath E, Biggerstaff A et al (2015) Sediment impacts on marine sponges. Mar Pollut Bull 94:5-13. https://doi.org/10.1016/ j.marpolbul.2015.03.030

Bergquist DC, Crowe SE (2009) Using historical data and meta-analyses to improve monitoring and Management of Beach Nourishment in South Carolina. Final Report. Charleston

Bernaert K (2013) Masterplan Kustveiligheid. http://www.vliz.be/ imisdocs/publications/243661.pdf. Accessed 14 Mar 2019

Bird E, Lewis N (2015) Beach Renourishment. Springer International Publishing, Cham

BMAPA and The Crown Estate (2017) Good practice guidance: extraction by dredging of aggregates from England's seabed, London

Bournemouth Borough Council (2017) Beach Management Scheme - A 17-year plan to protect Bournemouth's coastline. https://www. bournemouth.gov.uk/AttractionsLeisure/BeachesandWaterfront/ BeachManagementScheme/BeachManagementScheme.aspx. Accessed 9 Aug 2017

Brock KA, Reece JS, Ehrhart LM (2009) The effects of Artificial Beach nourishment on marine turtles: differences between loggerhead and green turtles. Restor Ecol 17:297-307. https://doi.org/10.1111/j. 1526-100X.2007.00337.x

Brown S, Nicholls RJ, Woodroffe CD et al (2013) Sea-level rise impacts and responses: a global perspective. In: Finkl C (ed) Coastal Hazards. Spinger, pp 117-149

Brown JM, Phelps JJC, Barkwith A, Hurst MD, Ellis MA, Plater AJ (2016) The effectiveness of beach mega-nourishment, assessed over three management epochs. J Environ Manag 184:1-9. https://doi. org/10.1016/j.jenvman.2016.09.090

Buceta Miller JL, España. Ministerio de Fomento, CEDEX, (2004) Guía metodológica para la elaboración de estudios de impacto ambiental de las extracciones de arenas para la regeneración de playas. Ministerio de Fomento, Secretaría General Técnica, Centro de Publicaciones, Madrid

Burgess K, Jay H, Nicholls RJ, Green C, Penning-Rowsell EC (2007) Assessment of future coastal erosion risk. In: Thorne CR, Evans EP, Penning-Rowsell EC (eds) Future flooding and coastal erosion risks. Thomas Telford Publishing, London, p 528

Burlas M, Ray G. L., Clarke D (2001) The New York District's biological monitoring program for the Atlantic Coast of New Jersey, Asbury Park to Manasquan Section Beach Erosion control project. Final Report. New York

Campbell TJ, Benedet L (2006) Beach nourishment magnitudes and trends in the U.S. J Coast Res:57-64

Capobianco M, Stive MJF (2000) Soft intervention technology as a tool for integrated coastal zone management. J Coast Conserv 6:33-40. https://doi.org/10.1007/BF02730465

Carley JT, Cox RJ (2017) Guidelines for sand nourishment. WRL Research Report 263. Manly Vale 
Carroll B, Turpin T (2002) Environmental impact assessment handbook: a practical guide for planners, developers and communities, Reprinted. Thomas Telford

Cheong S-M, Silliman B, Wong PP, van Wesenbeeck B, Kim CK, Guannel G (2013) Coastal adaptation with ecological engineering. Nat Clim Chang 3:787-791. https://doi.org/10.1038/nclimate1854

Colosio F, Abbiati M, Airoldi L (2007) Effects of beach nourishment on sediments and benthic assemblages. Mar Pollut Bull 54:1197-1206. https://doi.org/10.1016/j.marpolbul.2007.04.007

Cooke BC, Jones AR, Goodwin ID, Bishop MJ (2012) Nourishment practices on Australian sandy beaches: a review. J Environ Manag 113:319-327. https://doi.org/10.1016/j.jenvman.2012.09.025

Crain DA, Bolten AB, Bjorndal KA (1995) Effects of beach nourishment on sea turtles: review and Research initiatives. Restor Ecol 3:95-104

CSA International, Inc. et al (2010) Analysis of potential biological and physical impacts of dredging on offshore ridge and shoal features. OCS Study MMS 2010-2010

Davison AT, Nicholls RJ, Leatherman SP (1992) Beach nourishment as a coastal management tool. An Annotated Bibliography on Developments Associated with the Artificial Nourishment of Beaches. J Coast Res 8:984-1022

De Backer A, Moulaert I, Hillewaert H et al (2010) Monitoring the effects of sand extraction on the benthos of the Belgian part of the North Sea. Report ILVO-Animal Sciences-Fisheries, Oostende

De Jong MF, Baptist MJ, van Hal R et al (2014) Impact on demersal fish of a large-scale and deep sand extraction site with ecosystem-based landscaped sandbars. Estuar Coast Shelf Sci 146:83-94. https://doi. org/10.1016/j.ecss.2014.05.029

de Jong MF, Baptist MJ, Lindeboom HJ, Hoekstra P (2015) Short-term impact of deep sand extraction and ecosystem-based landscaping on macrozoobenthos and sediment characteristics. Mar Pollut Bull 97: 294-308. https://doi.org/10.1016/j.marpolbul.2015.06.002

de Jong MF, Borsje BW, Baptist MJ, van der Wal JT, Lindeboom HJ, Hoekstra P (2016) Ecosystem-based design rules for marine sand extraction sites. Ecol Eng 87:271-280

De Jonge VN (1983) Relations between annual dredging activities, suspended matter concentrations, and the development of the tidal regime in the ems estuary. Can J Fish Aquat Sci 40:289-300. https:// doi.org/10.1139/183-290

De Jonge VN, Schückel U (2019) Exploring effects of dredging and organic waste on the functioning and the quantitative biomass structure of the ems estuary food web by applying input method balancing in ecological network analysis. Ocean Coast Manag 174:38-55. https://doi.org/10.1016/j.ocecoaman.2019.03.013

de Schipper MA, de Vries S, Ruessink G, de Zeeuw RC, Rutten J, van Gelder-Maas C, Stive MJF (2016) Initial spreading of a mega feeder nourishment: observations of the sand engine pilot project. Coast Eng 111:23-38. https://doi.org/10.1016/j.coastaleng.2015.10.011

Dean RG (2002) Beach nourishment: theory and practice. World Scientific Publishing Co. Pte. Ltd., Singapore

Dean C (2009) Surfers Deal a blow to a beach dredging project. New York Times

DEME (2017) References: Lincshore Beach Renournishment, 2010-2015

Derweduwen J, Vandendriessche S, Hostens K (2009) Monitoring the effects of the Thorntonbank and Bligh Bank wind farms on the epifauna and demersal fish fauna of soft bottom sediments. ILVO Fisheries Report, Ostend

Dette HH, Gärtner J (1987) Erfahrungen mit der Versuchssandvorspülung vor Hörnum im Jahre 1983. Die Küste 45:209-258

Directive 2014/52/EU of the European Parliament and of the Council (2014) Off J Eur Union 124:1-18

Ebbens E (2016) Notitie reikwijdte en detailniveau winning suppletiezand Noordzee 2018-2027

Environment Agency (2009) Lincshore 2010-2015 scoping report. Bristol
Environment Agency (2017) Press release: £6.8m Lincshore scheme starts soon to reduce coastal flood risk. Flooding Coast. Chang

Environment Protection and Biodiversity Conservation Act (EPBC) (1999) Australian Government

Erchinger HF (1975) Schutz sandiger Küsten in Abhängigkeit vom Schutzdünen-Strand-Profil. Die Küste 27:19-27

Erchinger HF (1986) Strandaufspülungen als aktiver Küstenschutz vor Schutzwerken und Dünen auf Norderney und Langeoog. Die Küste 43:181-204

Erchinger HF, Tillmann B (1992) Die versuchsorientierte Strandaufspülung Norderney 1989. Die Küste 54:143-168

Erftemeijer PLA, Riegl B, Hoeksema BW, Todd PA (2012) Environmental impacts of dredging and other sediment disturbances on corals: a review. Mar Pollut Bull 64:1737-1765. https://doi.org/ 10.1016/j.marpolbul.2012.05.008

Essink K (1999) Ecological effects of dumping of dredged sediments; options for management. J Coast Conserv 5:69-80. https://doi.org/ 10.1007/BF02802741

Essink K, Birklund J, Madsen HT et al (1997) Risk analysis of coastal nourishment techniques (RIACON) - final evaluation report. Haren, NL

European Commission (2008) Directive 2008/56/EC of the European Parliament and of the council. Off J Eur Union 164:19-40. https:// doi.org/10.1016/j.biocon.2008.10.006

Federale Overheidsdienst (2014) Regelementering zand- en grindwinning in het Belgische deel van de Noordzee (in Dutch). Report D/2013/2295/17

Fiselier J (2010) MER Zandmotor Delftlandse kust. EIA Zandmotor (in Dutch)

Fonseca A, Sánchez LE, Ribeiro JCJ (2017) Reforming EIA systems: a critical review of proposals in Brazil. Environ Impact Assess Rev 62:90-97. https://doi.org/10.1016/j.eiar.2016.10.002

Führböter A, Dette H-H (1992) Strandvorspülungen vor der Westküste von Sylt. Die Küste 53:51-126

Führböter A, Köster R, Kramer J et al (1972) Sandbuhne vor Sylt zur Stranderhaltung. Die Küste 23:1-62

Führböter A, Köster R, Kramer J et al (1976) Beurteilung der Sandvorspülung 1972 und Empfehlungen für die künftige Stranderhaltung am Weststrand der Insel Sylt. Die Küste 29:23-95

Gracia V, Sánchez-Arcilla A, Anfuso G (2013) Spain. In: Pranzini E, Thomas A (eds) Coastal Erosion and protection in Europe. Routledge, London, p 488

Greene K (2002) Beach nourishment: a review of the biological and physical impacts. In: ASMFC habitat management series \#7, Washington

Hamm L, Capobianco M, Dette H et al (2002) A summary of European experience with shore nourishment. Coast Eng 47:237-264. https:// doi.org/10.1016/S0378-3839(02)00127-8

Hanson H, Brampton A, Capobianco M, Dette HH, Hamm L, Laustrup C, Lechuga A, Spanhoff R (2002) Beach nourishment projects, practices, and objectives - a European overview. Coast Eng 47:81-111. https://doi.org/10.1016/S0378-3839(02)00122-9

Harvey N, Caton B (2010) Coastal Management in Australia. University of Adelaide Press

Hedrick C (2000) State, Territory, and Commonwealth Beach Nourishment Programs. A National Overview

Herrera A, Gomez-Pina G, Fages L, de la Casa A, Muñoz-Perez JJ (2010) Environmental impact of beach nourishment: a case study of the Rio san Pedro beach (SW Spain). Open Oceanogr J 4:32-41. https://doi. org/10.1093/acref/9780199641666.013.5337

Highley DE, Hetherington LE, Brown TJ et al (2007) The strategic importance of the marine aggregate industry to the UK, Nottingham

Hillen R, Roelse P (1995) Dynamic preservation of the coastline in the Netherlands. J Coast Conserv 1:17-28. https://doi.org/10.1007/ BF02835558 
Holloman KT, Godfrey MH (2008) Sea turtle monitoring project report, Bogue banks, North Carolina. 2002-2007 final report

Holzhauer H, van der Valk B, van Dalfsen J, et al (2009) Ecologisch gericht suppleren, nu en in de toekomst: het ontwerp meerjarenplan voor monitoring en (toepassingsgericht) onderzoek. Deltares rapport 1200689-000-ZKS-0009. Delft

Hughes R (1998) Environmental impact assessment and stakeholder involvement. In: A directory of impact assessment guidelines, 2nd edn. International Institute for Environment and Development, London, pp 21-30

IMDC (2010) MER voor de extractie van mariene aggregaten in de exploratiezone van het Belgisch deel van de Noordzee. I/RA/ $11361 / 10.043 / \mathrm{RDS}$

IPCC (2018) Summary for policymakers. In: Masson-Delmotte V, Zhai $\mathrm{P}$, Pörtner $\mathrm{H}-\mathrm{O}$ et al (eds) Global warming of $1.5^{\circ} \mathrm{C}$, an IPCC special report on the impacts of global warming of $1.5^{\circ} \mathrm{C}$ above preindustrial levels. World Meteorological Organization, Geneva, pp $1-24$

Janssen G, Mulder S (2005) Zonation of macrofauna across sandy beaches and surf zones along the Dutch coast. Oceanologia 47: 265-282

Jarrett JT (1987) Beach nourishment - A Corps perspective. U.S. Army Corps of Engineers, Coastal Engineering Research Board 48th Meeting, Savannah, GA

Jay S, Jones C, Slinn P, Wood C (2007) Environmental impact assessment: retrospect and prospect. Environ Impact Assess Rev 27:287300. https://doi.org/10.1016/j.eiar.2006.12.001

Jha-Thakur U, Fischer TB (2016) 25 years of the UK EIA system: strengths, weaknesses, opportunities and threats. Environ Impact Assess Rev 61:19-26. https://doi.org/10.1016/j.eiar.2016.06.005

Jones SR, Mangun WR (2001) Beach nourishment and public policy after hurricane Floyd: where do we go from here? Ocean Coast Manag 44:207-220. https://doi.org/10.1016/S0964-5691(01)00046-1

Jones AR, Murray A, Lasiak TA, Marsh RE (2008) The effects of beach nourishment on the sandy-beach amphipod Exoediceros fossor: impact and recovery in Botany Bay, New South Wales, Australia. Mar Ecol 29:28-36. https://doi.org/10.1111/j.1439-0485.2007.00197.x

Jones R, Bessell-Browne P, Fisher R, Klonowski W, Slivkoff M (2016) Assessing the impacts of sediments from dredging on corals. Mar Pollut Bull 102:9-29. https://doi.org/10.1016/j.marpolbul.2015.10.049

Karman P, Mijnders I, Verbeek I, Argiolu R (2013) Milieueffectrapport Kustversterking Hondsbossche en Pettemer Zeewering. Zwakke Schakels Noord-Holland, Hoorn

Kosmynin V, Edwards L, Peterson J, Biggs B (2016) Standard operation procedures for nearshore hardbottom monitoring of beach nourishment projects. Tallahassee

Kramer J (1958) Die Strandaufspülung Norderney 1951-1952 und ein Plan zu ihrer Fortführung. Die Küste 7:107-139

Kystdirektoratet (2015a) Coastal Protection in Denmark. http://eng.kyst. dk/coastal-protection-in-denmark.html. Accessed 23 Jun 2017

Kystdirektoratet (2015b) Coastal Protection on the West Coast of Jutland. http://eng.kyst.dk/coastal-protection-on-the-west-coast-of-jutland. html. Accessed 28 Feb 2019

Leewis L, van Bodegom PM, Rozema J, Janssen GM (2012) Does beach nourishment have long-term effects on intertidal macroinvertebrate species abundance? Estuar Coast Shelf Sci 113:172-181. https://doi. org/10.1016/j.ecss.2012.07.021

Ley 21/2013 (2013) Gobierno de España

Luijendijk A, Hagenaars G, Ranasinghe R, Baart F, Donchyts G, Aarninkhof S (2018) The state of the World's beaches. Sci Rep 8: 6641. https://doi.org/10.1038/s41598-018-24630-6

Luo S, Liu Y, Jin R, Zhang J, Wei W (2016) A guide to coastal management: benefits and lessons learned of beach nourishment practices in China over the past two decades. Ocean Coast Manag 134:207-215. https://doi.org/10.1016/j.ocecoaman.2016.10.011
Mangor K, Drønen N, Kærgaard KH, Kristensen SE (2017) Shoreline Management Guidelines. Hørsholm

MAPAMA (2016) Estrategia de Adaptación al Cambio Climático de la Costa Española

McFarland S, Whitcombe L, Collins M (1994) Recent shingle beach renourishment schemes in the UK: some preliminary observations. Ocean Coast Manag 25:143-149. https://doi.org/10.1016/09645691(94)90044-2

MDK (2011) Masterplan Kustveiligheid

MELUR-SH (2012) Generalplan Küstenschutz des Landes SchleswigHolstein (Fortschreibung 2012). Kiel

Menn I, Junghans C, Reise K (2003) Buried alive: effects of beach nourishment on the infauna of an erosive shore in the North Sea. Senckenberg Marit 32:125-145

Mielck F, Hass HC, Michaelis R, Sander L, Papenmeier S, Wiltshire KH (2018) Morphological changes due to marine aggregate extraction for beach nourishment in the German bight (SE North Sea). GeoMarine Lett 39:47-58. https://doi.org/10.1007/s00367-018-0556-4

Miljø- og Fødevareministeriet (2018) Bekendtgørelse af lov om miljøvurdering af planer og programmer og af konkrete projekter (VVM). LBK nr 1225 af 25/10/2018. Miljø- og Fødevareministeriet

Moses CA, Williams RBG (2008) Artificial beach recharge: the South East England experience. Z Geomorphol 52:107-124. https://doi. org/10.1127/0372-8854/2008/0052S3-0107

Muñoz-Perez JJ, de San Lopez, Roman-Blanco B, Gutierrez-Mas JM et al (2001) Cost of beach maintenance in the Gulf of Cadiz (SW Spain). Coast Eng 42:143-153

National Environmental Policy Act (NEPA) (1970) United States Environmental Protection Agency

National Research Council (1994) Restoring and protecting marine habitat: the role of engineering and technology. National Academies Press, Washington

National Research Council (1995) Beach nourishment and protection. National Academies Press, Washington

Neumann B, Vafeidis AT, Zimmermann J, Nicholls RJ (2015) Future coastal population growth and exposure to sea-level rise and coastal flooding - a global assessment. PLoS One 10:e0118571. https://doi. org/10.1371/journal.pone. 0118571

NLWKN (2010) Generalplan Küstenschutz Niedersachsen Ostfriesische Inseln. Norden

Oost A, Van der Lelij AC, De Bel M et al (2016) The usability of the sand motor concept. Delft

Parkinson RW, Ogurcak DE (2018) Beach nourishment is not a sustainable strategy to mitigate climate change. Estuar Coast Shelf Sci 212: 203-209. https://doi.org/10.1016/j.ecss.2018.07.011

Patterson Britton \& Partners Pty Ltd (2006) Scoping study on the feasibility to access the Cape Byron sand lobe for sand extraction for beach nourishment. Sydney

Peduzzi P (2014) Sand, rarer than one thinks. Nairobi, Kenya

Peterson CH, Bishop MJ (2005) Assessing the environmental impacts of beach nourishment. Bioscience 55:887-896

Pontee N (2013) Defining coastal squeeze: A discussion. Ocean Coast Manag 84:204-207. https://doi.org/10.1016/j.ocecoaman.2013.07.010

Rakocinski CF, Heard RW, LeCroy SE et al (1996) Responses by macrobenthic assemblages to extensive beach restoration at Perdido Key, Florida, USA. J Coast Res 12:326-353

Ramesh R, Chen Z, Cummins V, Day J, D'Elia C, Dennison B, Forbes DL, Glaeser B, Glaser M, Glavovic B, Kremer H, Lange M, Larsen JN, le Tissier M, Newton A, Pelling M, Purvaja R, Wolanski E (2015) Land-ocean interactions in the coastal zone: past, present and future. Anthropocene 12:85-98. https://doi.org/10.1016/j. ancene.2016.01.005

Rijkswaterstaat (2017) Jarkus. http://opendap.deltares.nl/thredds/catalog/ opendap/rijkswaterstaat/jarkus/catalog.html. Accessed 11 Mar 2019

Rogers J, Hamer B, Brampton A et al (2010) Beach management manual, 2nd edition. CIRIA, London 
Roos C, Cilliers DP, Retief FP, Alberts RC, Bond AJ (2020) Regulators' perceptions of environmental impact assessment (EIA) benefits in a sustainable development context. Environ Impact Assess Rev 81: 106360. https://doi.org/10.1016/j.eiar.2019.106360

Rosov B, Bush S, Roberts Briggs T, Elko N (2016) The state of understanding the impacts of beach nourishment activities on infaunal communities. Shore \& Beach 84:51-55

Rozemeijer MJC, de Kok J, de Ronde JG, et al (2013) Het Monitoring en Evaluatie Programma Zandwinning RWS LaMER 2007 en 20082012: overzicht, resultaten en evaluatie. IMARES Wageningen UR Rapport C181/13, Deltares Rapport 1207903-000-ZKS-004. Lelystad

Sanò M, Gonzalez-Riancho P, Areizaga J, Medina R (2010) The strategy for coastal sustainability: a Spanish initiative for ICZM. Coast Manag 38:76-96. https://doi.org/10.1080/08920750903411734

Schlacher TA, Noriega R, Jones A, Dye T (2012) The effects of beach nourishment on benthic invertebrates in eastern Australia: impacts and variable recovery. Sci Total Environ 435:411-417. https://doi. org/10.1016/j.scitotenv.2012.06.071

Schoonees T, Gijón Mancheño A, Scheres B, Bouma TJ, Silva R, Schlurmann T, Schüttrumpf H (2019) Hard structures for coastal protection, towards greener designs. Estuaries and Coasts 42: 1709-1729. https://doi.org/10.1007/s12237-019-00551-z

Schotte P (1999) Het Belgisch Continentaal Plat: Herdefiniëring van de grenzen van de concessiezones voor zandwinning en definiëring van de kabelzones

She K, Horn D, Canning P (2007) Influence of permeability on the performance of shingle and mixed beaches, London

Speybroeck J, Bonte D, Courtens W, et al. (2004) Studie over de impact van zandsuppleties op het ecosysteem, Eindrapport

Speybroeck J, Bonte D, Courtens W, Gheskiere T, Grootaert P, Maelfait JP, Mathys M, Provoost S, Sabbe K, Stienen EWM, Lancker VV, Vincx M, Degraer S (2006) Beach nourishment: an ecologically sound coastal defence alternative? A review. Aquat Conserv Mar Freshw Ecosyst 16:419-435. https://doi.org/10.1002/aqc.733

Speybroeck J, Hendrickx F, Degraer S, Vincx M (2007) The ecological impact of beach nourishment and the restrained habitat of key species: experimental insights and field data. In: Speybroeck, J. (2007). Ecologie van macrobenthos als een basis voor een ecologische bijsturing van strandsuppleties = ecology of macrobenthos as a baseline for an ecological adjustment of beach nourishment. pp 125-139

StALU MM (2009) Regelwerk Küstenschutz MecklenburgVorpommern. Rostock

Stive MJF, de Schipper MA, Luijendijk AP, Aarninkhof SGJ, van Gelder-Maas C, van Thiel de Vries JSM, de Vries S, Henriquez M, Marx S, Ranasinghe R (2013) A new alternative to saving our beaches from sea-level rise: the sand engine. J Coast Res 290:10011008. https://doi.org/10.2112/JCOASTRES-D-13-00070.1

Sutton G, Boyd S (eds) (2009) Effects of Extraction of Marine Sediments on the Marine Environment 1998-2004. ICES Cooperative Research Report No. 297. Int Council Explor Sea (ICES)

Temmerman S, Meire P, Bouma TJ, Herman PMJ, Ysebaert T, de Vriend HJ (2013) Ecosystem-based coastal defence in the face of global change. Nature 504:79-83. https://doi.org/10.1038/nature12859

The Crown Estate (2017) Marine aggregates. Capability \& Portfolio 2017. London

The State of Victoria (2006) Ministerial guidelines for assessment of environmental effects under the environment effects act 1978, 7th edn. The State of Victoria Department of Sustainability and Environment, Melbourne

Tritel (2011a) Project "suppletie hoog strand" in de Panne, Verzoek to ontheffing van project-mer (in Dutch). Afdeling Kust Report 5195514-131-01

Tritel (2011b) Project "suppletie hoog strand" in Koksijde, Verzoek to ontheffing van project-mer (in Dutch). Afdeling Kust Report 5195 514-132-01
Tritel (2011c) Project "suppletie hoog strand" in de Haan-Wenduine, Verzoek tot ontheffing van project-mer (in Dutch). Afdeling Kust Report 5195

Tucker R, Parker J, Barnett L, et al (2005) Adelaide's living beaches - a strategy for 2005-2025

UNEP/MAP/PAP (2008) Protocol on Integrated Coastal Zone Management in the Mediterranean. Split

US Army Corps of Engineers (1989) Environmental Engineering for Coastal Protection

US Army Corps of Engineers (2002) Coastal engineering manual (CEM). U.S. Army Corps of Engineers

US EPA, USACE (2007) Identifying, planning, and financing beneficial use projects using dredged material: beneficial use planning manual. EPA 842-B-07-001. U.S. Environmental Protection Agency \& U.S. Army Corps of Engineers, Washington, DC

van Dalfsen JA, Essink K (2001) Benthic community response to sand dredging and shoreface nourishment in Dutch coastal waters. Senckenberg Marit 31:329-332. https://doi.org/10.1007/ BF03043041

van Duin C, Vrij Peerdeman M, Jaspers H, Bucholc A (2017) Winning suppletiezand Noordzee $2018 \mathrm{t} / \mathrm{m}$ 2027. Milieueffectrapportage, De Bilt

Van Egmond EM, van Bodegom PM, Berg MP, Wijsman JWM, Leewis L, Janssen GM, Aerts R (2018) A mega-nourishment creates novel habitat for intertidal macroinvertebrates by enhancing habitat relief of the sandy beach. Estuar Coast Shelf Sci 207:232-241. https://doi. org/10.1016/j.ecss.2018.03.003

van Lancker V, Lauwaert B, De Mol L. et al. (2015) Zand- en grindwinning (in Dutch). In: Pirlet,Verleye, Lescrauwaet and Mees, Compendium voor Kust en Zee 2015: Een geintegreerd kennisdocument over de socio-economische, ecologische en institutionele aspecten van de kust en zee in Vlaanderen en België. Oostende, Belgium, pp. 109-118

van Rijn LC (2010) Coastal erosion control based on the concept of sediment cells

Van Rijn LC (2011) Coastal erosion and control. Ocean Coast Manag 54: 867-887. https://doi.org/10.1016/j.ocecoaman.2011.05.004

Vanden Eede S (2013) Impact of beach nourishment on coastal ecosystems with recommendations for coastal policy in Belgium. Universiteit Ghent

Vanden Eede S, Van Tomme J, De Busschere C et al (2014) Assessing the impact of beach nourishment on the intertidal food web through the development of a mechanistic-envelope model. J Appl Ecol 51: 1304-1313. https://doi.org/10.1111/1365-2664.12314

Velegrakis AF, Ballay A, Poulos S et al (2010) European marine aggregates resources: origins, usage, prospecting and dredging techniques. J Coast Res:1-14. https://doi.org/10.2112/si51-002.1

Verhagen HJ (1992) Method for Artificial Beach Nourishment. Coast Eng 1992:1-12

Vikolainen V, Flikweert J, Bressers H, Lulofs K (2017) Governance context for coastal innovations in England: the case of Sandscaping in North Norfolk. Ocean Coast Manag 145:82-93. https://doi.org/10.1016/j.ocecoaman.2017.05.012

Walker R, Bokuniewicz H, Carlin D, et al (2016) Effects of extraction of marine sediments on the marine environment 2005-2011. ICES Cooperative Research Report No 330

Walvin SA, Mickovski SB (2015) A comparative study of beach nourishment methods in selected areas of the coasts of the United Kingdom and the Netherlands. WIT Trans Built Environ 148:8596. https://doi.org/10.2495/CC150081

Werritty A (2007) Driver impacts in Scotland. In: Thorne C, Evans E, Penning-Rowsell E (eds) Future flooding and coastal erosion risks. Thomas Telford Publishing, London, pp 227-243

Wilmink RJA, Lodder QJ, Sørensen P (2017) Assessment of the design and behaviour of nourishments in the North Sea region. Towards an NSR guideline for nourishments. In: Coastal Dynamics 2017. pp. 801-809 
Woodruff JD, Irish JL, Camargo SJ (2013) Coastal flooding by tropical cyclones and sea-level rise. Nature 504:44-52. https://doi.org/10. 1038/nature 12855

Wooldridge T, Henter HJ, Kohn JR (2016) Effects of beach replenishment on intertidal invertebrates: a 15 -month, eight beach study. Estuar Coast Shelf Sci 175:24-33. https://doi.org/10.1016/j.ecss. 2016.03.018

Young R (2019) Beach Nourishment as Storm Protection: Its Impact on Sediment Budgets and Ecosystems. Geophys Res Abstr 19 21: 11652
Young R, Coburn A (2017) Beach nourishment in the USA, the history, the impacts, and the future. In: Geophysical Research Abstracts 17

Zeiler M, Figge K, Griewatsch K et al (2004) Regenerierung von Materialentnahmestellen in Nord- und Ostsee. Die Küste 68:67-98

Publisher's note Springer Nature remains neutral with regard to jurisdictional claims in published maps and institutional affiliations. 